\title{
Biomarkers geochemistry of the Alpagut oil shale sequence: an evaluation of dispositional environments and source rock potential from Dodurga-Çorum basin (N-Turkey)
}

\author{
S. Korkmaz ${ }^{1} \cdot$ R. Kara-Gülbay ${ }^{1}$ (i) $\cdot$ T. Khoitiyn ${ }^{1} \cdot$ M. S. Erdoğan ${ }^{1}$
}

Received: 29 October 2021 / Accepted: 27 December 2021 / Published online: 13 January 2022

(c) The Author(s) 2022

\begin{abstract}
The Cenozoic Çankırı-Çorum basin, with sedimentary facies of varying thickness and distribution, contains raw matters such as coal deposits, oil shales and evaporate. Source rock and sedimentary environment characteristics of the oil shale sequence have been evaluated. The studied oil shales have high organic matter content (from 2.97 to $15.14 \%$ ) and show excellent source rock characteristics. Oil shales are represented by very high hydrogen index (532-892 mg HC/g TOC) and low oxygen index (8-44 $\mathrm{mgCO}_{2} / \mathrm{g}$ TOC) values. Pyrolysis data indicate that oil shales contain predominantly Type I and little Type II kerogen. The biomarker data reveal the presence of algal, bacterial organic matter and terrestrial organic matter with high lipid content. These findings show that organic matters in the oil shales can generate hydrocarbon, especially oil. High $\mathrm{C}_{26} / \mathrm{C}_{25}, \mathrm{C}_{24} / \mathrm{C}_{23}$ and low $\mathrm{C}_{22} / \mathrm{C}_{21}$ tricyclic terpane, $\mathrm{C}_{31} \mathrm{R} / \mathrm{C}_{30}$ hopane and DBT/P ratios indicate that the studied oil shales were deposited in a lacustrine environment, and very low $\mathrm{Pr} / \mathrm{Ph}$ ratio is indicative of anoxic character for the depositional environment. $\mathrm{T}_{\max }$ values from the pyrolysis analysis are in the range of $418-443{ }^{\circ} \mathrm{C}$, and production index ranges from 0.01 to 0.08 . On the gas chromatography, high $\mathrm{Pr} / \mathrm{nC}_{17}$ and $\mathrm{Ph} / \mathrm{nC}_{18}$ ratios and $\mathrm{CPI}$ values significantly exceeding 1 were determined. Very low $22 \mathrm{~S} /(22 \mathrm{~S}+22 \mathrm{R})$ homohopane, $20 \mathrm{~S} /(20 \mathrm{~S}+20 \mathrm{R})$ sterane, diasterane/sterane and $\mathrm{Ts} /(\mathrm{Ts}+\mathrm{Tm})$ ratios were calculated from the biomarker data. Results of all these analyses indicate that Alpagut oil shales have not yet matured and have not entered the oil generation window.
\end{abstract}

Keywords Çankırı-Çorum basin $\cdot$ Oil shale $\cdot$ Biomarkers $\cdot$ Depositional environment $\cdot$ Hydrocarbon potential

\section{Introduction}

The Çankırı-Çorum basin which was filled with approximately $4 \mathrm{~km}$ thick Cenozoic deposits is noticeable in respect to its potential of hydrocarbon source rocks and evaporitic minerals (Kaymakçı 2000; Yavuz and Demirer 2018; Yavuz et al. 2017).

The Çankırı-Çorum basin is located in a complex region on the İzmir-Ankara-Erzincan suture zone which realized by the collision of Kırşehir and Sakarya continents in the Late Cretaceous (Ketin 1966; Birgili et al. 1975; Şengör and Yılmaz 1981; Kaymakçı 2000; Özçelik and Öztaş 2000; Uğuz et al. 2002; Yavuz and Demirer 2018). The northern

\section{R. Kara-Gülbay}

kara@ktu.edu.tr

1 Department of Geological Engineering, Karadeniz Technical University, Trabzon, Turkey branch of Neotethys Ocean (İzmir-Ankara-Erzincan Ocean) began to subduct northward beneath the Sakarya continent in the early Cretaceous, and the Kırşehir and Sakarya continents were collided in the late Cretaceous (Şengör and Yllmaz 1981; Barrier et al., 2018). Following the collision, the Kurşehir continent started to rotate counterclockwise, and this rotation initiated a tectonic regime dominated by strike-slip faults during the Paleocene-Early Eocene. During this time, the basin was witnessed a marine transgression. Starting from the middle Eocene, south-vergent thrust faults developed around the basin and old units were pushed over the young units. This was followed by uplifting and shallowing of the basin. At the end of Middle Eocene, the sea was completely receded giving rise to formation of a terrestrial intermountain basin during late Eocene-Oligocene (Tüysüz and Dellaloğlu 1994; Kaymakçı 2000). Deposition in this closed basin, which resulted from vertical tectonic movements, continued uninterruptedly until the end of the Upper Miocene (Şenalp, 1981). The study area was inundated by 
an open semi-tropic lake with abundant organic matter during Early Middle Miocene. During this period, coal layers were deposited along the lakeshore. Evaporitic lacustrine units were deposited during the late Miocene-Pliocene depending on the changes in climatic conditions (Tüysüz and Dellaloğlu 1994; Varol et al. 2002; Zengin 2006).

The Alpagut coal and oil shale deposits occur in the Miocene sequences on the northeastern margin of ÇankırıÇorum basin covering a large area in the Central Anatolia having a basement comprising Paleozoic metamorphic and Upper Cretaceous ophiolitic rocks. Basement rocks are overlain locally by Upper Cretaceous clastic deposits and commonly by Paleogene-Neogene clastics, carbonates, evaporitic deposits and volcanics.

The Alpagut coal and oil shale field is situated $51 \mathrm{~km}$ northwest of Çorum city and $7 \mathrm{~km}$ west of Dodurga town (Fig. 1). Coal deposits in the region have been known for a long time and Blumenthal (1938), Kıpçak (1947), Bender (1955), Pekmezciler (1957), Wedding (1966) and Kara et al. (1990) conducted first geological studies on them. Following the drilling works in the basin, coal deposit became exploited. Micropaleontological, petrographic and organic geochemical characteristics of the coal sequence were carried out by Turnovsky (1964), Toprak (1996) and YalçınErik et al. (2018), respectively. The coal level in the region is overlain by $141 \mathrm{~m}$ thick oil shale sequence. 138 million tons of probable oil shale reserve were discovered in the basin (Taka et al., 1982). Oil shales have ash ratio of $75.20 \%$, water content of $0.90-16.15 \%$, density of $2.32 \mathrm{gr} / \mathrm{cm}^{3}$, bitumen ratio of $2.5 \%$ and calorific value of $70-870 \mathrm{kcal} / \mathrm{kg}$ (Taka et al. 1992). Taka et al. (1992) carried out the first geological study on the oil shale sequence. Khoitiyn (2016) examined the source rock potential of the sequence using the pyrolysis data.
Works in the studied basin were generally focused on coal deposits, and there are limited works on geological, fossil fuel and source rock characteristics and reserve estimation of the oil shales. However, organic geochemical features of these shales are not studied. Therefore, this study aims to clarify depositional environment, organic matter input, source rock and hydrocarbon potential of Alpagut oil shales using the pyrolysis/TOC, GC and biomarker data.

\section{Geological setting}

Geological characteristics of the study area, based on field observations and previous works by Birgili et al. (1975), Taka et al. (1992) and Toprak (1996), are summarized below (Figs. 1 and 2). The oldest exposed rocks are represented by Eocene rocks in the study area which are represented by three Eocene units, and the Hacihalil Formation consists of dark-light gray, thick-bedded conglomerate, sandstone and siltstone alternation. It is conformably overlain by the Yoncalı Formation comprising gray, beige, light green colored turbiditic sandstone, siltstone, marl, shale, limestone and mudstone interlayers. The Narlı Volcanites were emplaced by cutting the Eocene aged Yoncalı Formation. The Narlı Volcanites consisting of basalt, andesite, agglomerates and tuffs represent the upper level of the Eocene units (Toprak, 1996).

Miocene lacustrine deposits in the basin unconformably overlie the Eocene units. Miocene aged Kızılırmak Formation represented by conglomerate, siltstone and reddish brown and light brown clays occurs at the lower part of the Miocene sequence. The clay unit contains lignite layers and lignite laminas of varying thickness. Miocene aged Dodurga Formation begins with lignite coal level and continues with
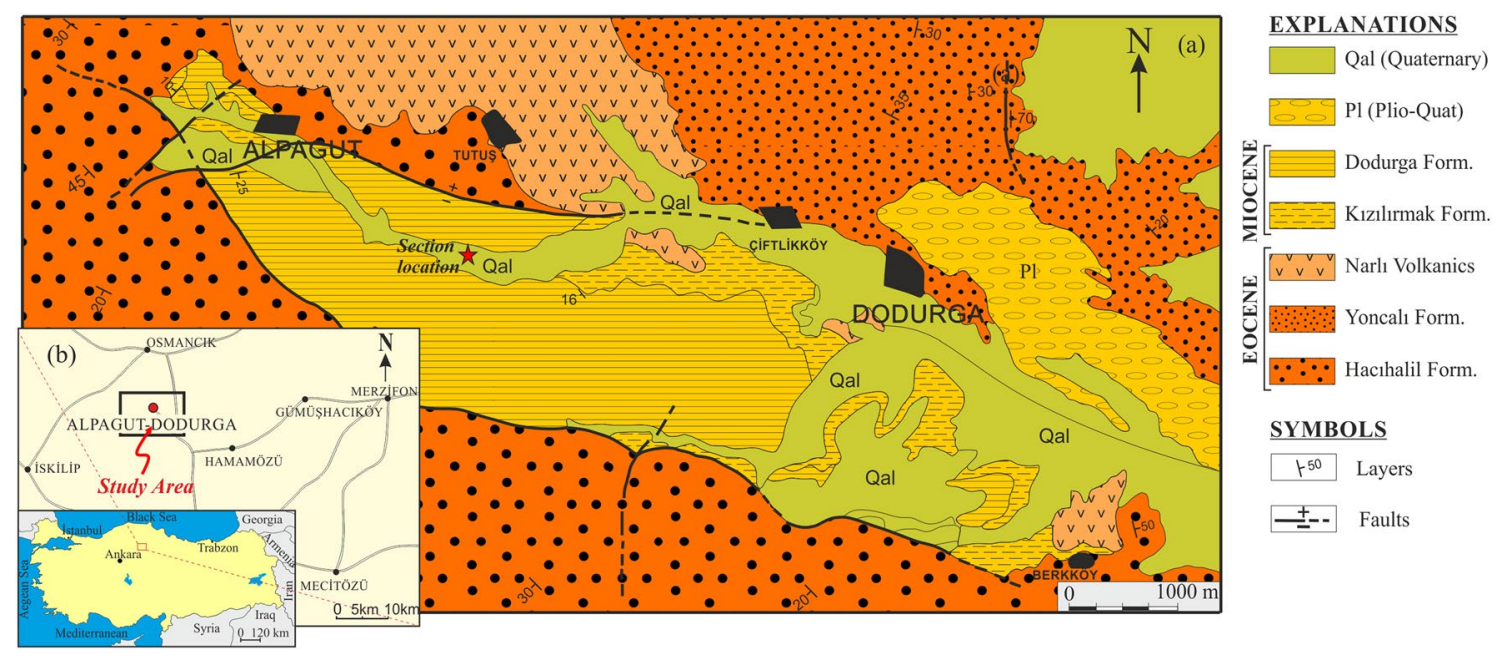

Fig. 1 Geological map of the Alpagut-Dodurga region ( modified from Taka et al., 1992) (a) and location map of study area (b)

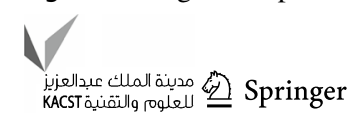




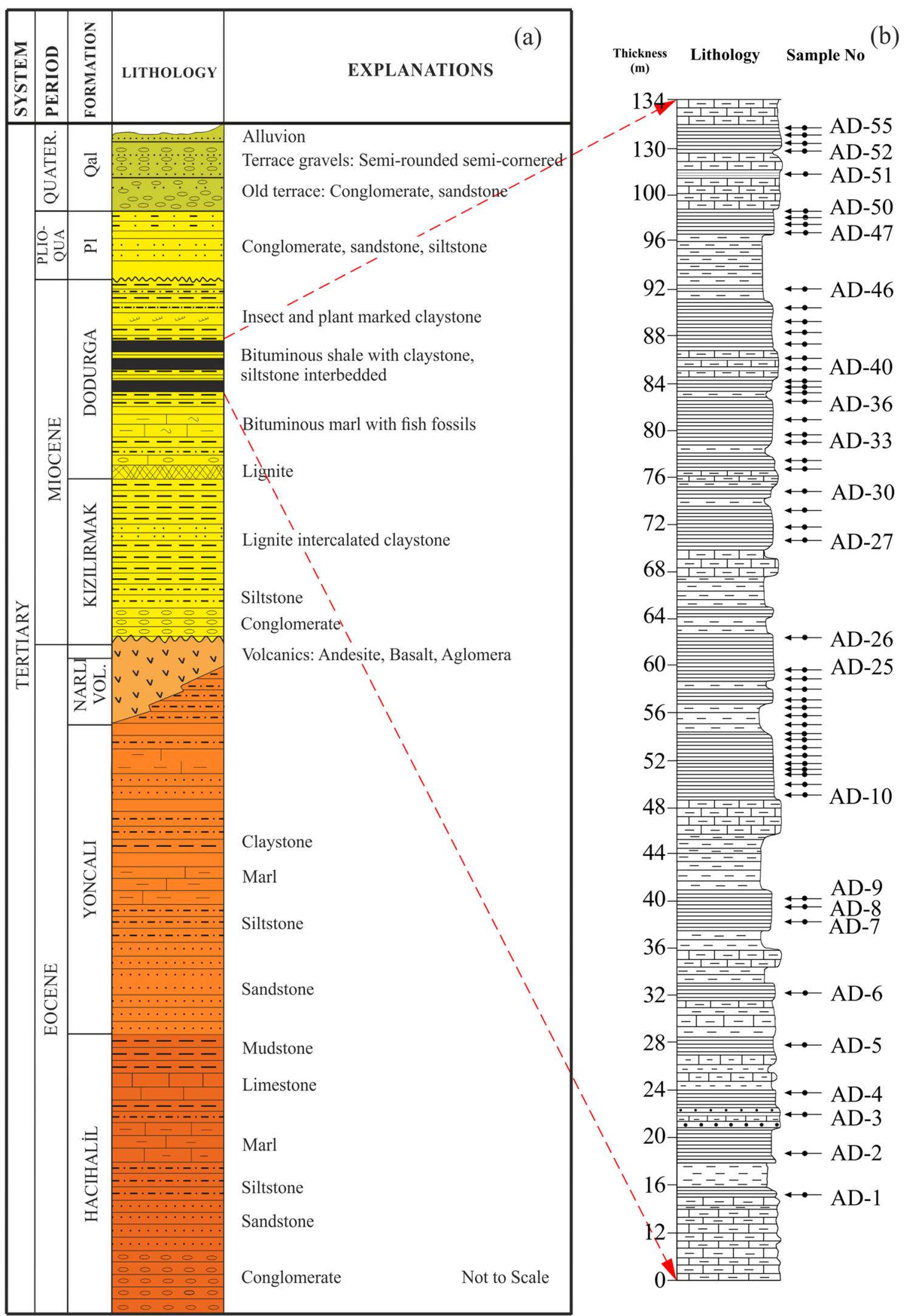

Fig. 2 Generalized stratigraphic section of the Alpagut-Dodurga region (Taka et al., 1992) (a) and measured stratigraphic section of the oil shale sequence (b) 
siltstone and marls with abundant fish fossils and oil shales to the top. This level is not homogeneous and locally alternated with claystone, marl and siltstone. Plio-Quaternary units unconformably lie on the Miocene and Eocene units. They are characterized by loosely compacted conglomerates, fine-medium sandstones, and yellowish, gray, beige colored siltstones of $100 \mathrm{~m}$ thickness. Quaternary deposits that consist of loosely cemented conglomerates and sandstones unconformably overlie all the underlying units (Fig. 2).

The oil shale sequence in the study area occurs at the upper level of the Miocene Dodurga Formation. The stratigraphic section of oil shale sequence was measured in the Alpagut open-pit coal mine as $134 \mathrm{~m}$ and the sequence consisting of sandstone-limestone-siltstone-marl interlayers contains 17 different oil shale levels with thickness varying from 20 to $5.5 \mathrm{~m}$ (Figs. 2 and 3).

\section{Materials and methodology}

The stratigraphic section of oil shale sequence was measured in the Alpagut open-pit coal mine, and oil shale levels were systematically sampled from bottom to top along the sequence. Rock-Eval/TOC analysis was performed on 54 oil shale samples selected to represent oil shales at different levels. Taking into account the pyrolysis data obtained, samples AD-2 and AD-47 were selected to represent the bottom and upper levels of the succession, respectively, and GC and GC-MS analyzes were performed on these samples. Gas chromatography (GC) (bulk extract), gas chromatography-mass spectrometry (GC-MS) (saturated hydrocarbonssterane and terpane/aromatic hydrocarbons-monoaromatic and triaromatic steroids, phenanthrene and methyl-phenanthrenes, dibenzothiophene, and methyl-dibenzothiophenes) analyses were conducted on extracts obtained from two oil shale samples (AD-2, AD-47). Rock Eval/TOC, GC and GC-MS analyses were carried out at the Geochemistry Laboratories of Turkish petroleum corporation (TPAO).

$100 \mathrm{mg}$ of 54 powdered samples which were systematically collected from oil shales of the Dodurga Formation was subjected to Rock-Eval pyrolysis/TOC analyses by using a Rock-Eval 6 instrument equipped with a TOC module. In the pyrolysis process, the sample was heated from 300 (hold time $3 \mathrm{~min}$ ) to $650{ }^{\circ} \mathrm{C}$ at $25^{\circ} \mathrm{C} / \mathrm{min}$. In the oxidation process, the sample was heated from 400 (holding time $3 \mathrm{~min}$ ) to $850{ }^{\circ} \mathrm{C}$ (hold time $5 \mathrm{~min}$ ) at $25^{\circ} \mathrm{C} / \mathrm{min}$ for oxidation.

The $\mathrm{C}_{15+}$ soluble organic matter (SOM) was isolated following Soxhlet extraction $(40 \mathrm{~h})$ of the powdered rock samples with dichloromethane $\left(\mathrm{CH}_{2} \mathrm{Cl}_{2}\right)$. Whole shale extracts were analyzed using a Varian 3400 gas chromatograph equipped
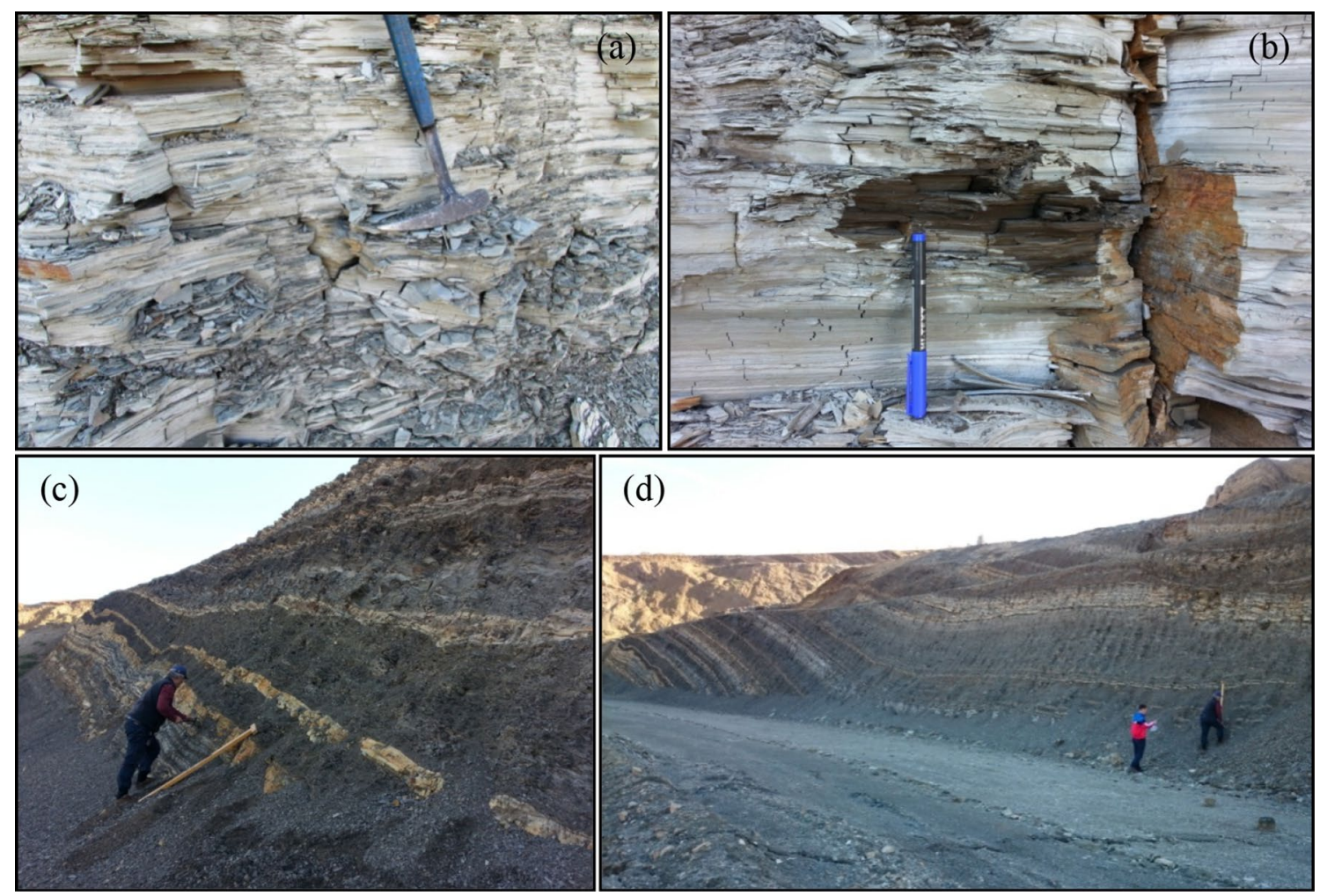

(d)

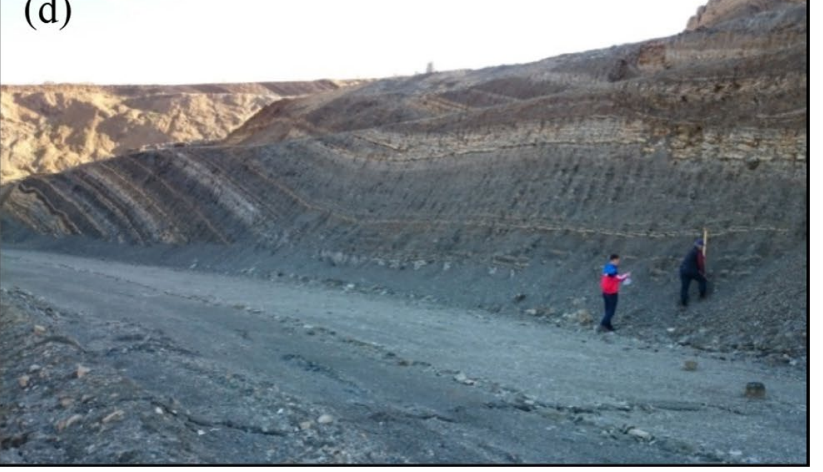

Fig. 3 Field photographs of Dodurga oil shale in Alpagut open coal mine site. Close up view of oil shale occurrence (a, b); General view of the oil shale sequence $(\mathbf{c}, \mathbf{d})$ 


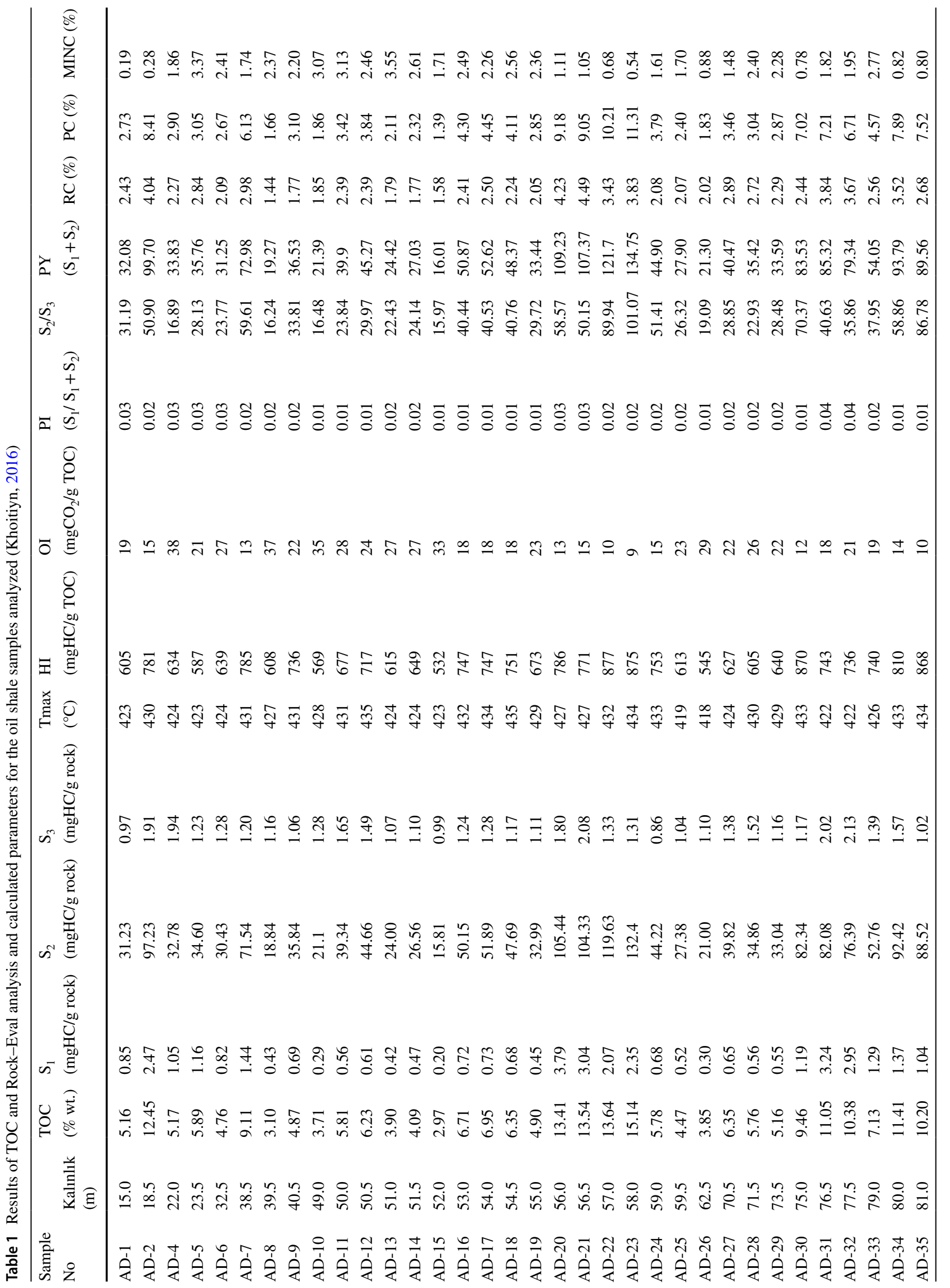




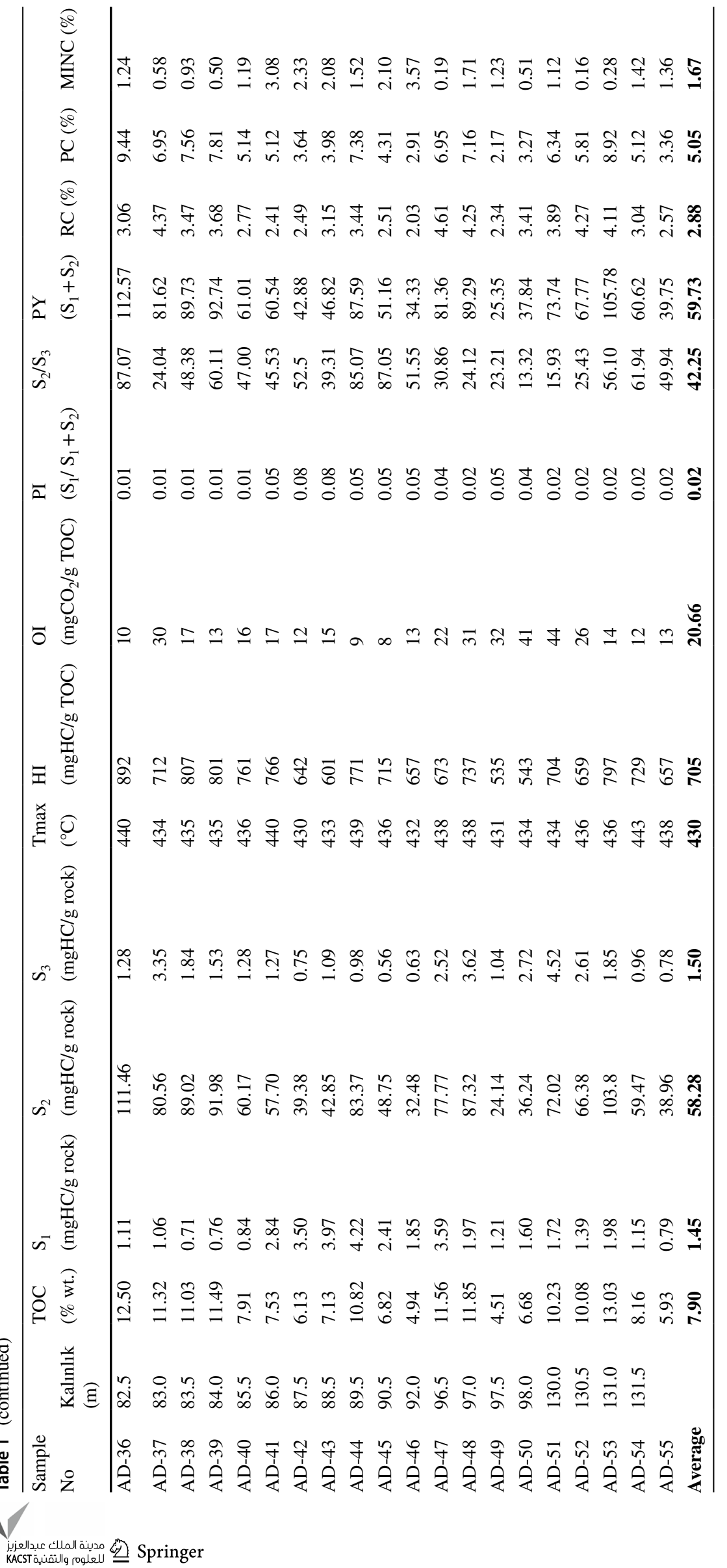


Fig. 4 Gas chromatograms of the oil shale extracts analyzed. a oil shale sample AD-2, b oil shale sample AD-47
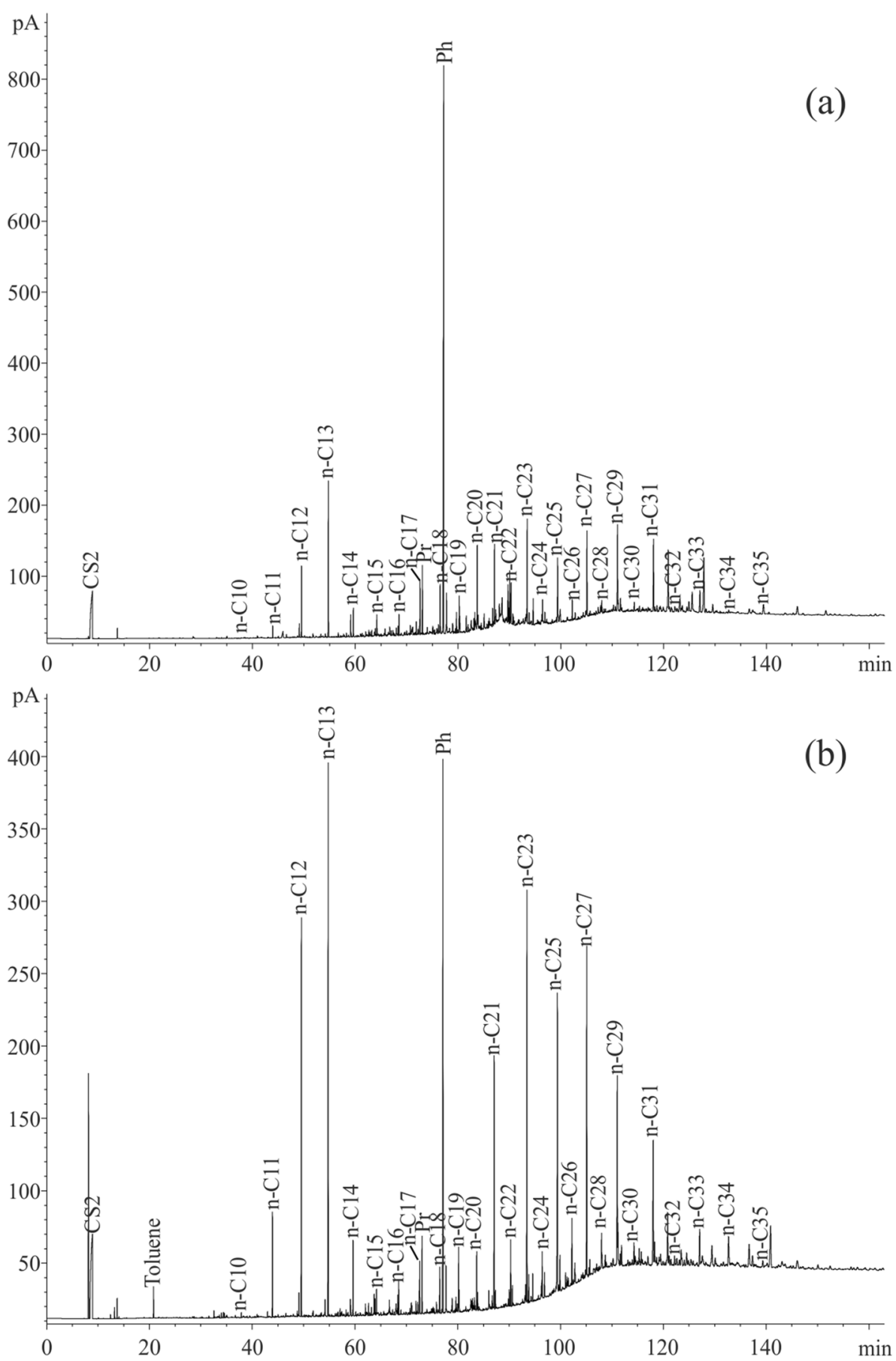

Table 2 Parameters calculated from gas chromatograms of the oil shale extracts analyzed

\begin{tabular}{llllll}
\hline Sample No & $\mathrm{Pr} / \mathrm{Ph}$ & $\mathrm{Pr} / \mathrm{nC}_{17}$ & $\mathrm{Ph} / \mathrm{nC}_{18}$ & $\mathrm{CPI}_{(24-34)}$ & $\mathrm{TAR}$ \\
\hline $\mathrm{AD}-2$ & 0.12 & 1.48 & 11.82 & 6.20 & 2.33 \\
$\mathrm{AD}-47$ & 0.12 & 1.25 & 11.76 & 5.73 & 4.47 \\
\hline
\end{tabular}

with flame photometric (FPD) and flame ionization detectors (FID). A fused capillary column (60 m, $0.20 \mathrm{~mm}$ i.d.) coated with cross-linked dimethylpolysiloxane (J\&W, $0.25 \mu \mathrm{m}$ film thickness) was used. Helium was the carrier gas. The oven temperature was programmed from 40 (hold time $8 \mathrm{~min}$ ) to $270^{\circ} \mathrm{C}$ (hold time $60 \mathrm{~min}$ ) at $4^{\circ} \mathrm{C} / \mathrm{min}$.

Shale extracts were de-asphaltened using $n$-pentane and were fractioned by thin-layer chromatography (MKIatroscan). $n$-hexane, toluene, and methanol were used for extract separation into saturated hydrocarbons, aromatic 

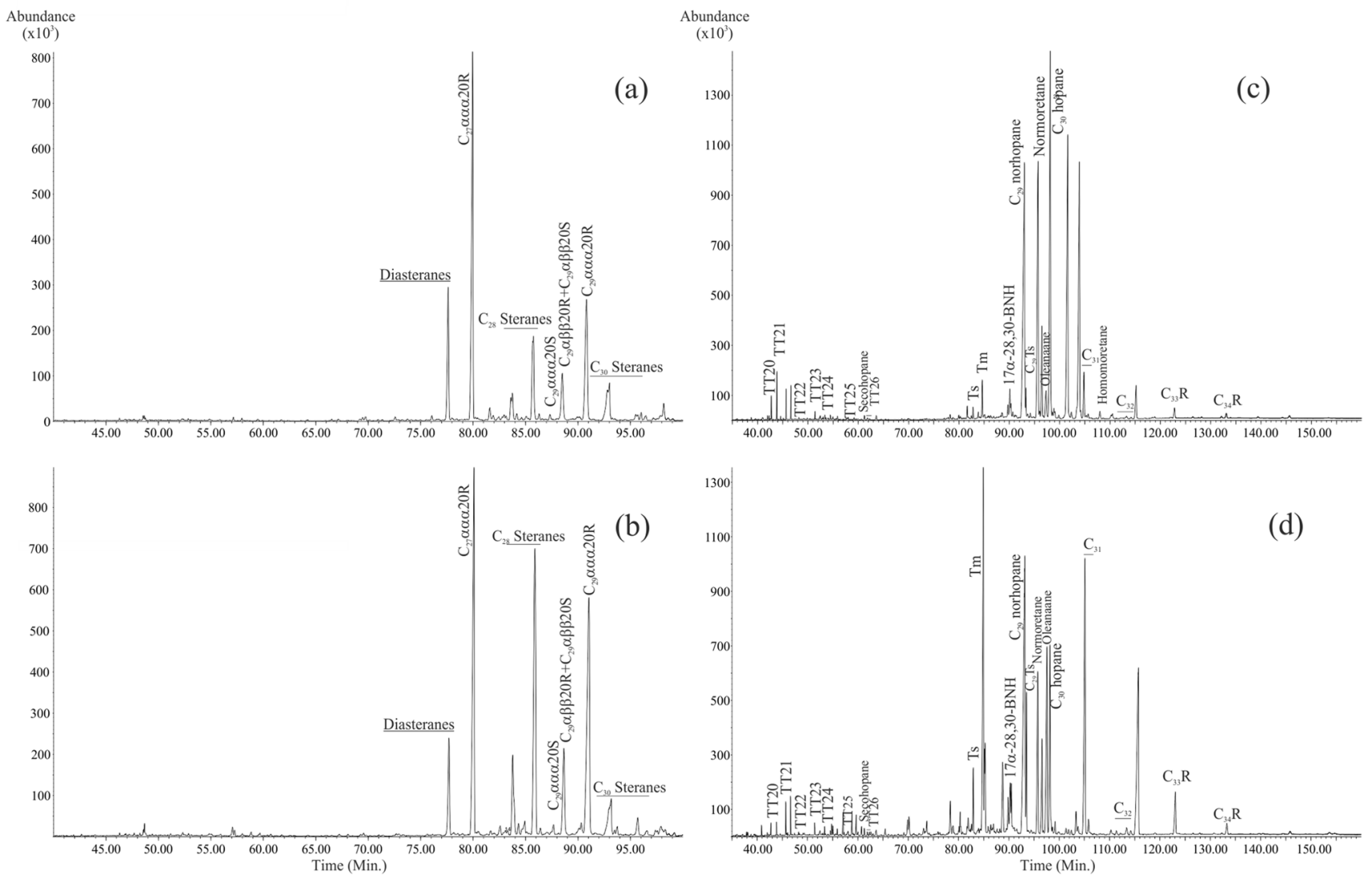

Fig. $5 \mathrm{~m} / \mathrm{z} 217$ mass chromatograms showing the distribution of aliphatic steroid (a, b) and m/z 191 mass chromatograms showing the distribution of the aliphatic hopanoid (c, d) of Alpagut oil shale samples (AD-2 and AD-47, respectively)

hydrocarbons, and NSO fractions, respectively. GC-MS analyses were performed on the saturated, aromatic and NSO fractions using an Agilent 5975C quadruple mass spectrometer coupled to a 7890A gas chromatograph and a 7683B automatic liquid sampler. The gas chromatograph was equipped with an HP-1MS fused silica capillary column of $60 \mathrm{~m}$ length, $0.25 \mathrm{~mm}$ i.d., and $0.25 \mu \mathrm{m}$ film thickness. Helium was used as the carrier gas. The oven temperature was programmed from 50 (hold time $10 \mathrm{~min}$ ) to $200^{\circ} \mathrm{C}$ (hold time $15 \mathrm{~min}$ ) at $10^{\circ} \mathrm{C} / \mathrm{min}$, to $250^{\circ} \mathrm{C}$ (hold time $24 \mathrm{~min}$ ) at $5^{\circ} \mathrm{C} / \mathrm{min}$ and then to $280^{\circ} \mathrm{C}$ (hold time $24 \mathrm{~min}$ ) at $2^{\circ} \mathrm{C} /$ min. Finally, the oven temperature was increased to $290^{\circ} \mathrm{C}$ (hold time $40 \mathrm{~min}$ ) at $1^{\circ} \mathrm{C} / \mathrm{min}$. The mass spectrometer was operated in EI mode at ionization energy of $70 \mathrm{eV}$ and a source temperature of $300^{\circ} \mathrm{C}$. The biomarker contents were determined using single-ion recordingly at $\mathrm{m} / \mathrm{z} 191$ for tri-, tetra- and pentacyclic triterpanes, at $\mathrm{m} / \mathrm{z} 217$ for steranes and rearranged steranes, at $\mathrm{m} / \mathrm{z} 253$ for monoaromatic steranes, at $\mathrm{m} / z 231$ for triaromatic steranes, at 178 and 192 for phenanthrene and methyl-phenanthrene, and at $\mathrm{m} / \mathrm{z}, 187$ and 198 for dibenzothiophene and methyl-dibenzothiophenes. Compounds were identified by their retention time and elution order matching.

\section{Results}

\section{Bulk organic geochemical characteristics}

TOC values of oil shales of the Dodurga Formation in the Alpagut area are in the range of $2.97-15.14 \%$ with average of $7.9 \%$ (Table 1). Oil shales have very high $\mathrm{S}_{2}, \mathrm{~S}_{2} / \mathrm{S}_{3}$ and PY values. They are characteristic with particularly very high HI (varying from 532 to $892 \mathrm{mg} \mathrm{HC} / \mathrm{g}$ TOC with average of $705 \mathrm{mg} \mathrm{HC} / \mathrm{g}$ TOC) and low OI values (varying from 8 to $44 \mathrm{mg} \mathrm{HC} / \mathrm{g} \mathrm{CO}_{2}$ with average of $21 \mathrm{mg} \mathrm{HC/g} \mathrm{CO}$ ). $\mathrm{T}_{\max }$ was measured $418-443^{\circ} \mathrm{C}$ (average $\mathrm{T}_{\max } 430^{\circ} \mathrm{C}$ ). PI values are from 0.01 to 0.08 with average of 0.02 (Table 1 ).

\section{Molecular geochemistry of organic matter}

\section{n-alkanes and isoprenoids}

The n-alkanes in the $\mathrm{C}_{10}-\mathrm{C}_{35}$ range were recorded from the gas chromatograms. A bimodal distribution, where $\mathrm{C}_{13}$ is the maximum peak and $\mathrm{C}_{23}$ is recorded at a significant rate (Fig. 4), was observed. Pyhtane was recorded as being in very high concentrations compared to pristane, and the $\mathrm{Pr} /$ 
Table 3 Biomarker compositions based on $\mathrm{m} / \mathrm{z}, 191$, $217,231,253,178,192,187$ 198 mass chromatograms and calculated parameters for the oil shale extract

\begin{tabular}{|c|c|c|c|c|c|}
\hline \multirow[t]{2}{*}{ Terpanes } & \multicolumn{2}{|l|}{ Sample No } & \multirow[t]{2}{*}{ Steroids } & \multicolumn{2}{|l|}{ Sample No } \\
\hline & AD-2 & $\mathrm{AD}-47$ & & $\mathrm{AD}-2$ & $\mathrm{AD}-47$ \\
\hline $\mathrm{C}_{22} / \mathrm{C}_{21} \mathrm{tt}$ & 0.50 & 0.07 & $\mathrm{C}_{27}, \mathrm{C}_{28}, \mathrm{C}_{29}$ MA steroid (\%) & $21,48,31$ & $14,65,21$ \\
\hline $\mathrm{C}_{24} / \mathrm{C}_{23} \mathrm{tt}$ & 0.46 & 0.67 & $\mathrm{MA}(\mathrm{I}) / \mathrm{MA}(\mathrm{I}+\mathrm{II})$ & 0.08 & 0.04 \\
\hline$\left(\mathrm{C}_{19}+\mathrm{C}_{20}\right) / \mathrm{C}_{23} \mathrm{tt}$ & 3.14 & 1.04 & $\mathrm{TA}(\mathrm{I}) / \mathrm{TA}(\mathrm{I}+\mathrm{II})$ & 0.11 & 0.05 \\
\hline $\mathrm{Ts} /(\mathrm{Ts}+\mathrm{Tm})$ & 0.23 & 0.45 & $\mathrm{TA}\left[\mathrm{C}_{20} /\left(\mathrm{C}_{20}+\mathrm{C}_{28} \cdot 20 \mathrm{R}\right)\right]$ & 0.80 & 0.25 \\
\hline $\mathrm{C}_{31} \mathrm{R} \mathrm{HH} . / \mathrm{C}_{30} \mathrm{H}$ & 0.01 & 0.07 & $\mathrm{C}_{28}-\mathrm{TA} /\left(\mathrm{C}_{29}-\mathrm{MA}+\mathrm{C}_{28}-\mathrm{TA}\right)$ & & \\
\hline $\mathrm{C}_{23} \mathrm{tt} /\left(\mathrm{C}_{23} \mathrm{tt}+\mathrm{C}_{30} \mathrm{H}\right)$ & 0.02 & 0.06 & $\mathrm{C}_{29} /\left(\mathrm{C}_{28}+\mathrm{C}_{29}\right) \mathrm{MA}$ & 0.40 & 0.24 \\
\hline $\mathrm{C}_{26} / \mathrm{C}_{25} \mathrm{tt}$ & 1.67 & 1.83 & Phenanthrenes & & \\
\hline $\mathrm{C}_{29} / \mathrm{C}_{30}$ hopane & 0.69 & 1.44 & MPI-1 & 0.24 & 0.13 \\
\hline $\mathrm{C}_{29} \mathrm{Ts} /\left(\mathrm{C}_{29} \mathrm{H}+\mathrm{C}_{29} \mathrm{Ts}\right)$ & 0.09 & 0.33 & MPI-2 & 0.32 & 0.15 \\
\hline $\mathrm{C}_{30} * / \mathrm{C}_{29} \mathrm{Ts}$ & 0.17 & 0.02 & MPI-3 ( $\beta / \alpha$ MP) & 1.49 & 1.34 \\
\hline $\mathrm{C}_{30} * /\left(\mathrm{C}_{30} \mathrm{H}+\mathrm{C}_{30} *\right)$ & 0.01 & 0.01 & MPR & 2.31 & 1.40 \\
\hline (oleanane/ $\mathrm{C}_{30}$ hopane) $* 100$ & 7 & 100 & MPR1 & 0.05 & 0.04 \\
\hline $22 \mathrm{~S} /(22 \mathrm{~S}+22 \mathrm{R})\left(\mathrm{C}_{32}\right) \mathrm{H}$ & 0.30 & 0.41 & MPR9 & 0.07 & 0.03 \\
\hline sterane/hopane & 0.87 & 0.46 & MPR2 & 0.12 & 0.05 \\
\hline Steranes & & & MPR3 & 0.06 & 0.04 \\
\hline $\mathrm{C}_{27}, \mathrm{C}_{28}, \mathrm{C}_{29}$ ste. (\%) & $57,16,27$ & $34,35,31$ & 1-MP/9-MP & 0.78 & 1.22 \\
\hline $\mathrm{n}-$, iso-, diasterane $(\%)$ & $8,74,17$ & $15,77,8$ & Dibenzothiophenes & & \\
\hline $20 \mathrm{~S} /(20 \mathrm{~S}+20 \mathrm{R}) \mathrm{C}_{29}$ & 0.04 & 0.03 & MDR & 4.25 & 3.31 \\
\hline$\beta \beta /(\beta \beta+\alpha \alpha)$ & 0.27 & 0.26 & MDR' & 0.81 & 0.77 \\
\hline & & & $\mathrm{DBT} / \mathrm{P}$ & 0.05 & 0.03 \\
\hline
\end{tabular}

sterane/hopane $=\mathrm{C}_{27} . \quad \mathrm{C}_{28} . \quad \mathrm{C}_{29} \quad \alpha \alpha / \beta \beta \quad(20 \mathrm{~S}+20 \mathrm{R}) / \mathrm{C}_{29}-\mathrm{C}_{33} \quad$ hopane; $\quad \mathrm{MPI}-1=1.5(2 \mathrm{MP}+3 \mathrm{MP}) /$ $(\mathrm{P}+1 \mathrm{MP}+9 \mathrm{MP}) ; \mathrm{MPI}-2=3(2 \mathrm{MP}) /(\mathrm{P}+1 \mathrm{MP}+9 \mathrm{MP}) ;$

MPI-3 $=(2 \mathrm{MP}+3-\mathrm{MP}) /(1 \mathrm{MP}+9 \mathrm{MP}) ; \quad \mathrm{MPR}=2 \mathrm{MP} / 1 \mathrm{MP} ; \quad \mathrm{MPR}_{1}=1 \mathrm{MP} / \mathrm{P} ; \quad \mathrm{MPR}_{2}=2 \mathrm{MP} / \mathrm{P}$; $\mathrm{MPR}_{3}=3 \mathrm{MP} / \mathrm{P} ; \mathrm{MPR}_{9}=9 \mathrm{MP} / \mathrm{P} ; \mathrm{MDR}=4 \mathrm{MDBT} / 1 \mathrm{MDBT} ; \mathrm{MDR}^{\prime}=4 \mathrm{MDBT} /(1 \mathrm{MDBT}+4 \mathrm{MDBT}) ;$

$\mathrm{MA}(\mathrm{I}) / \mathrm{MA}(\mathrm{I}+\mathrm{II})=\left(\mathrm{C}_{21}+\mathrm{C}_{22}\right) /\left(\mathrm{C}_{21}+\mathrm{C}_{22}+\mathrm{C}_{27}+\mathrm{C}_{28}+\mathrm{C}_{29}\right) ; \quad \mathrm{TA}(\mathrm{I}) / \mathrm{TA}(\mathrm{I}+\mathrm{II})=\left(\mathrm{C}_{20}+\mathrm{C}_{21}\right) /$ $\left(\mathrm{C}_{20}+\mathrm{C}_{21}+\mathrm{C}_{26}+\mathrm{C}_{27}+\mathrm{C}_{28}\right.$
$\mathrm{Ph}$ ratio was calculated to be very low (mean 0.12 ) (Table 2). Pristane and pyhtane have been recorded at higher concentrations in comparison to $\mathrm{C}_{17}$ and $\mathrm{C}_{18}$ n-alkanes, especially the $\mathrm{Ph} / \mathrm{nC}_{18}$ ratio is very high. Odd-numbered n-alkanes are very dominant over even-numbered ones and have a very high CPI (Table 2).

\section{Biomarkers (saturated and aromatics)}

In m/z 191 mass chromatographs, a distribution in which tricyclic terpane contents are very low, $\mathrm{C}_{26} \mathrm{tt}$ is dominant over $\mathrm{C}_{25}$ tt and Tm dominant over Ts was determined. $\mathrm{C}_{31} \mathrm{R}$ $\mathrm{HH} / \mathrm{C}_{30} \mathrm{H}$ ratio is estimated very low. $\mathrm{C}_{30}$ *(diahopane) was recorded to be in trace amount while $\mathrm{C}_{29}$ Ts in significantly high quantity. Oleanane has been recorded in oil shale samples. Especially for the sample AD-47, the concentration of olenane and oleanane/ $\mathrm{C}_{30}$ hopane is very high (Table 1). $\mathrm{C}_{31}$ components are the most common homohopane, and other homohopanes are recorded either in trace amount or not recognized. $22 \mathrm{~S} /(22 \mathrm{~S}+22 \mathrm{R})\left(\mathrm{C}_{32}\right)$ homohopane ratio was calculated as 0.30 and 0.41 (Fig. 5c,d, Table 3). In m/z 217 mass chromatographs, diasteranes were recorded in very low abundance. $\mathrm{C}_{27}$ sterane is dominant over others for $\mathrm{AD}-2$ sample, while in the other samples (AD-47), $\mathrm{C}_{27}, \mathrm{C}_{28}$ and $\mathrm{C}_{29}$ steranes have similar abundances. Iso-steranes are much more abundant than $n$ - and dia-steranes. 20S/(20S + 20R) $\mathrm{C}_{29}, \beta \beta /(\beta \beta+\alpha \alpha)$ ratios were calculated as being very low (Fig. 5c, d, Table 3). In the studied oil shales, $\mathrm{C}_{21}$ and $\mathrm{C}_{22}$ monoaromatic steranes described as $\mathrm{MA}(\mathrm{I})$ are recorded as being in lower abundance compared to $\mathrm{C}_{27}, \mathrm{C}_{28}$ and $\mathrm{C}_{29}$ monoaromatic steranes described as MA(II). Similarly, $\mathrm{C}_{20}$ and $\mathrm{C}_{21}$ triaromatic steranes, defined as TA(I), were determined to be in lower abundances compared to $\mathrm{C}_{26}, \mathrm{C}_{27}$, $\mathrm{C}_{28}$ triaromatic steranes, known as TA(II) (Fig. 6). MA(I)/ $\mathrm{MA}(\mathrm{I}+\mathrm{II})$ and $\mathrm{TA}(\mathrm{I}) / \mathrm{TA}(\mathrm{I}+\mathrm{II})$ ratios were determined as being very low (Table 3 ). In general, $\mathrm{C}_{28}$ monoaromatic steroids are dominant, while $\mathrm{C}_{27} \mathrm{MA}$ steroids constitute the group with the lowest abundance. $\mathrm{C}_{29} /\left(\mathrm{C}_{28}+\mathrm{C}_{29}\right)$ MA ratios of the shale samples were found to be between 0.40 and 0.24 (Fig. 6, Table 3).

In m/z 178-m/z 192 mass chromatographs, $\mathrm{P}$ was recorded in very low abundance and MPs are in very low concentrations compared to Ps (Fig. 7a, b). MPR-1, 2, 3 and 9 ratios were calculated to be very low (Table 3 ). $2 \mathrm{MP}$ is more dominant than 

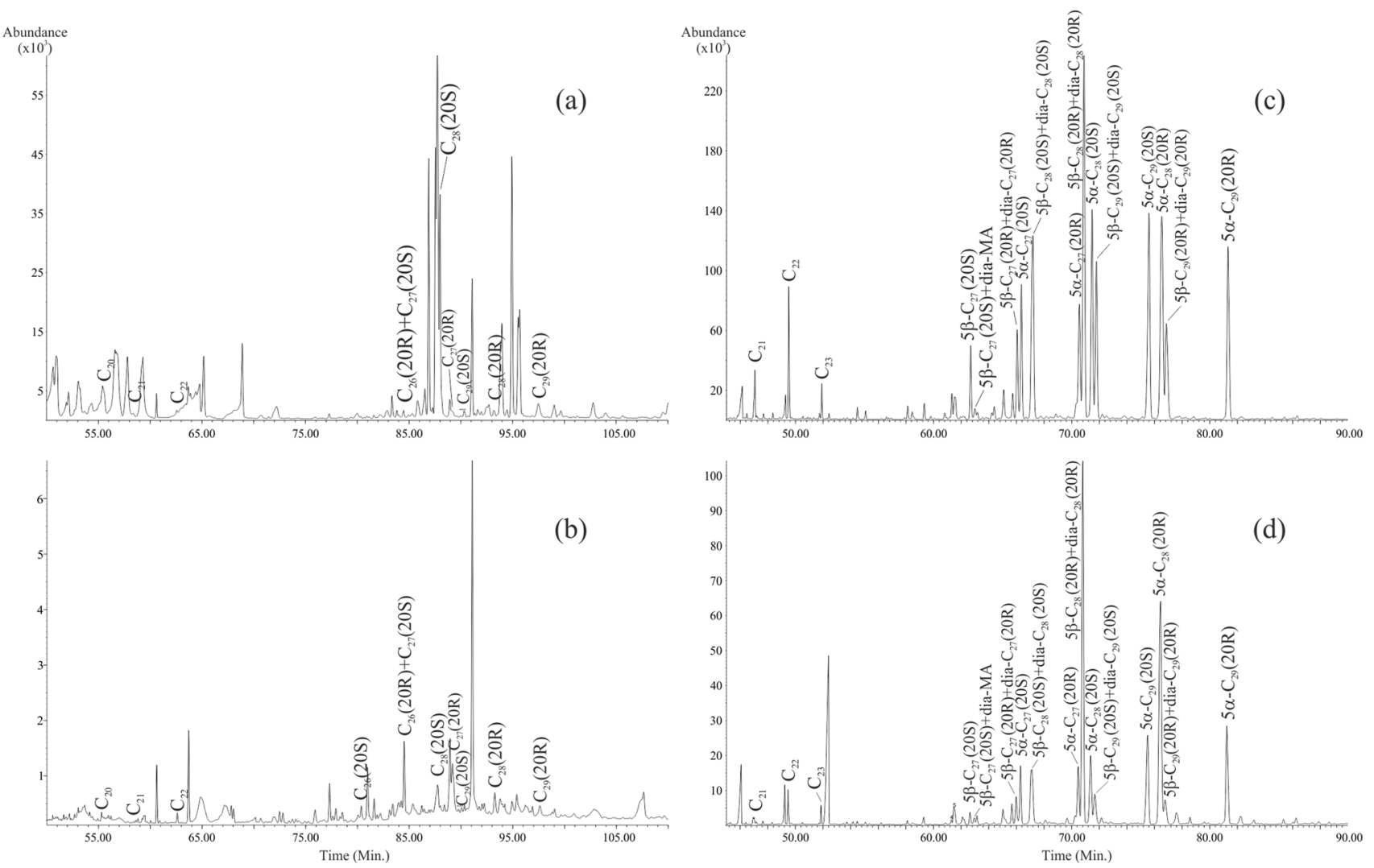

Fig. 6 Mass chromatograms $(\mathrm{m} / \mathrm{z}$ 231) showing the distribution of monoaromatic steroid hydrocarbons (a, b), and mass chromatograms $(\mathrm{m} / \mathrm{z}$ 253) showing the distribution of triaromatic steroid hydrocarbons (c, d) of Alpagut oil shale samples (AD-2 and AD-47, respectively)

other MPs (Fig. 7a, b). 9MP and 1MP generally have similar abundances, and for sample AD-2, 9MP was recorded in higher quantity than $1 \mathrm{MP}$, and for sample AD-47, 1MP dominates over 9MP (Fig. 7a, b). MPI-3 and MPR ratios are very high (Table 3). In m/z 184-m/z 198 mass chromatographs, 4MDBT is more dominant one, and 1MDBT constitutes the lowest abundant MDBT (Fig. 7c, d). For sample AD-47, DBT dominates over MDBTs, and for sample AD-47, DBT was recorded in lower quantity than 4MDBT (Fig. 7c, d) and MDR and MDR' ratios are very high (Table 3 ).

\section{Discussion}

TOC values varying from 2.97 to $15.14 \%$ indicate that the organic matter content of Alpagut oil shales is very high and has "excellent" source rock characteristics (Table 1, Fig. 8). High hydrogen index values ranging from 532 to $892 \mathrm{mg} \mathrm{HC} / \mathrm{g}$ TOC (average $705 \mathrm{mgHC} / \mathrm{gTOC}$ ) and high $\mathrm{S}_{2}$ (21.0-132.4 mg HC/mg rock) and low OI values indicate that oil shales contain predominantly Type I kerogen and little Type II kerogen (Table 1, Fig. 9). These characteristics reveal that organic matter of studied oil shales can generate hydrocarbon, dominantly oil (Table 1).

The n-alkane distribution with very high concentrations of high carbon numbers (in the range of $\mathrm{C}_{21}-\mathrm{C}_{31}$ ), which is observed in gas chromatograms of the studied oil shale samples and indicates terrestrial organic matter input, and TAR values calculated at very high values $(2.33-4.47)$ contradict the predominant Type I kerogen content interpretation done by pyrolysis data (Fig. 4, Table 2). High carbon numbered $n$-alkanes implying terrestrial organic matter are shown to be also associated with lacustrine algae (Gelpi et al. 1970; Peters et al. 2005; Riboulleau et al. 2007; Wang et al. 2011). Very high concentrations of $\mathrm{Ph}$ and very low estimated $\mathrm{Pr} / \mathrm{Ph}$ ratio $(0.12)$ indicate that oil shales deposited under anoxic conditions (Table 2). Very high $\mathrm{Pr} / \mathrm{n}-\mathrm{C}_{18}$ and lower $\mathrm{Ph} / \mathrm{C}_{17}$ ratios estimated for the studied oil shales imply algal organic matter, reducing deposition conditions and low maturity values (Fig. 10a, Table 2). $\mathrm{C}_{30}$ * is recorded in high quantities particularly in clay-rich rocks deposited under suboxic and oxic conditions and in source rocks with high terrestrial organic matter input (Philp and Gilbert 1986; Volkman et al. 1983). Trace amount of $\mathrm{C}_{30} *$ recorded in 


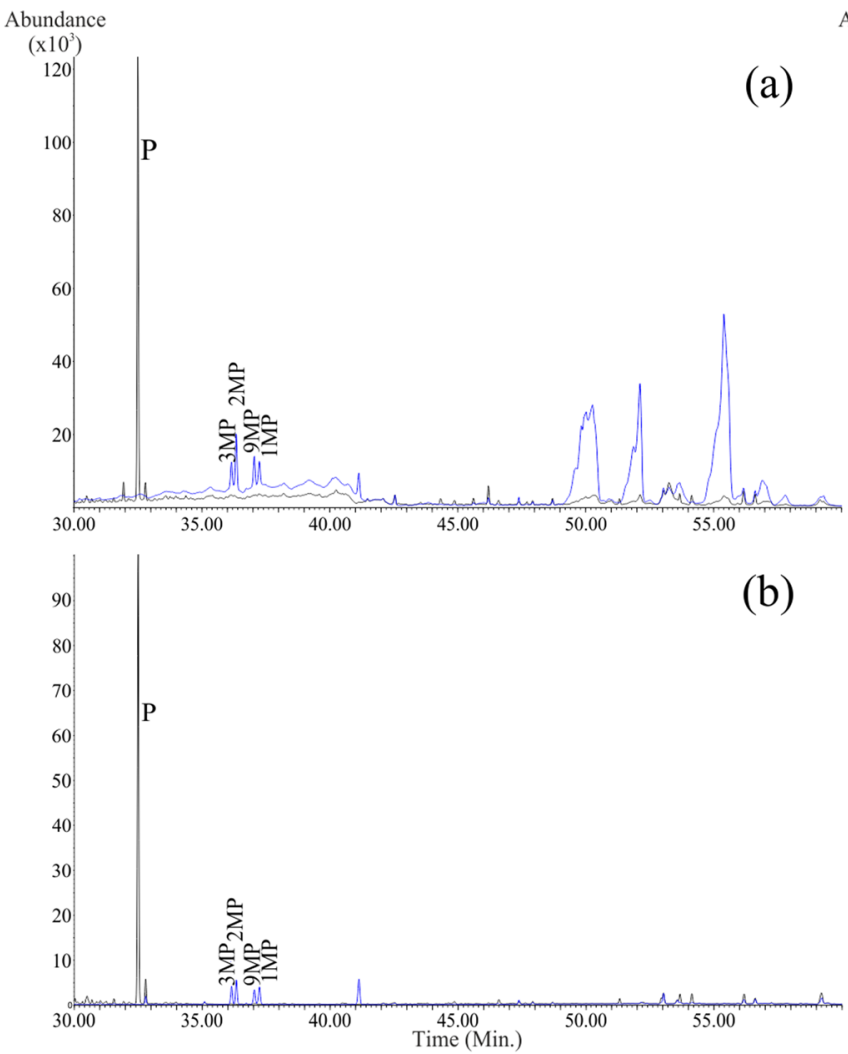

Fig. 7 a, b mass chromatograms (m/z 178 and 192) showing the distribution of phenanthrene and alkylphenanthrenes $(\mathrm{P}=$ phenanthrene; $\mathrm{MP}=$ methylphenanthrene $) ; \mathbf{c}, \mathbf{d}$ mass chromatograms $(\mathrm{m} / \mathrm{z} 184,198)$

the oil shales supports the interpretation anoxic deposition conditions revealed from $\mathrm{Pr} / \mathrm{Ph}$ (Fig. 5c, d).

In studied oil shales, $\mathrm{C}_{26}$ tricyclic terpane is much more abundant than $\mathrm{C}_{25}$ and $\mathrm{C}_{26} / \mathrm{C}_{25}$ ratios are in the range of 1.67 to 1.83 . In addition, oil shales have very low $\mathrm{C}_{31} \mathrm{R} /$ $\mathrm{C}_{30}$ hopane ratio (0.01-0.07) (Fig. 10b, Table 3). In general, the $\mathrm{C}_{22} / \mathrm{C}_{21}$ ratios are low, and the $\mathrm{C}_{24} / \mathrm{C}_{23}$ tricyclic terpane ratios are much higher (Fig. 10c). High $\mathrm{C}_{26} / \mathrm{C}_{25}, \mathrm{C}_{24} / \mathrm{C}_{23}$ and low $\mathrm{C}_{22} / \mathrm{C}_{21}$ tricyclic terpane ratios and having $\mathrm{C}_{31} \mathrm{R} / \mathrm{C}_{30}$ hopane ratios less than 0.25 indicate that studied oil shales were deposited in a lacustrine environment (Peters et al. 2005; Kara-Gülbay et al. 2012, 2019; Şengüler et al. 2014). High DBT and ADBT concentrations are characteristic for marine shales and carbonates, and their abundance is very low in terrestrial facies (Radke et al. 1991). DBT content lower than phenanthrene implies organic matter accumulated either in lacustrine or fluvial deltaic environments (Hughes et al. 1995). High $P$ and much lower DBT concentrations in the studied oil shales support the interpretation of lacustrine environment and in the DBT/P-Pr/Ph diagram, shales

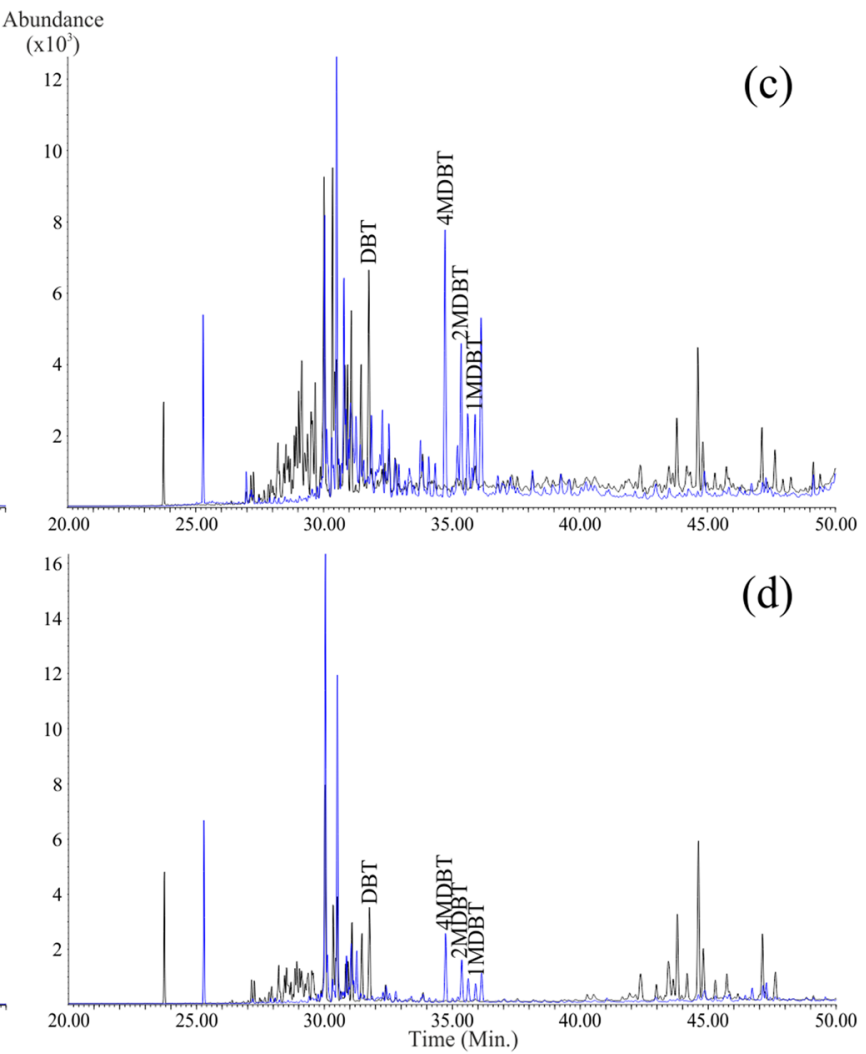

showing the distribution of dibenzothiophene and methyldibenzothiophene $(\mathrm{DBT}=$ dibenzothiophene, $\mathrm{MDBT}=$ methyldibenzothiophene $)$ of Alpagut oil shale samples (AD-2, AD-47, respectively)

samples with their very low $\mathrm{DBT} / \mathrm{P}$ and $\mathrm{Pr} / \mathrm{Ph}$ ratios are plotted in the "lacustrine sulphate-poor" field (Fig. 10d).

The determination of oleanane in two samples reveals that the age of the studied oil shales is Cretaceous or younger and the presence of terrestrial organic matter input (Whitehead 1973, 1974; Ekweozor et al. 1979; Grantham et al. 1983; Riva et al. 1988; Udo and Ekweozor 1990) (Fig. 5c, d). Having different oleanane abundance and oleanane index [(oleanane/hopane) *100] (Table 3) in both examples indicates that the amount of terrestrial input changes periodically. While the oleanane index of the sample taken from the lower levels of the sequence (AD-2) is 7 reflecting a weak terrestrial organic matter input, the oleanane index of the oil shale sample (AD-47) taken from the upper levels is 100 pointing to an important terrestrial organic matter input. Despite the high terrestrial organic matter content of the oil shale sample AD-47 (determined by the high oleanane content), the high HI value $(673 \mathrm{mgHC} / \mathrm{gTOC})$ indicates the Type I kerogen characteristic. This situation, which develops due to the presence of oleananes, can be explained by the 


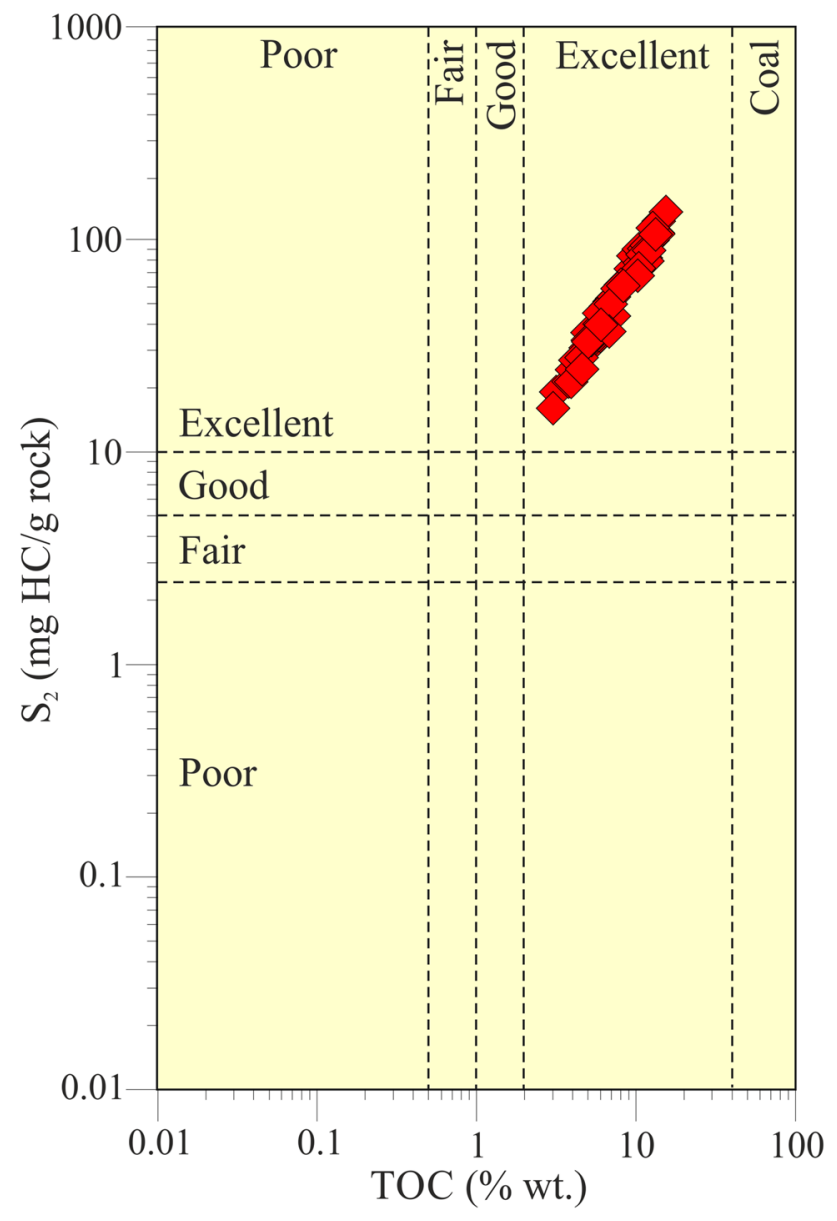

Fig. 8 Plot of Rock-Eval $S_{2}$ versus TOC (Dembicki, 2009) for the analyzed oil shale samples from Alpagut section, indicating the oil shales' excellent source rock potential

terrestrial organic matter input (Ekweozor and Udo 1988; Riva et al. 1988), which consists of angiosperms (belonging to Type I kerogen) having lipid-rich sections and producing abundant resin. Low regular sterane/hopane ratio is related to terrestrial and/or microbial organic matter (Tissot and Welte 1984). According to Moldowan et al. (1985), this ratio in non-marine oils is much lower than marine oils. The low sterane/hopane ratios calculated for studied oil shales (Table 3) might be related to their deposition in a lacustrine environment and their algal and significant bacterial organic matter contents as well.

$\mathrm{T}_{\max }$ values of $418-443^{\circ} \mathrm{C}$ (average $430{ }^{\circ} \mathrm{C}$ ) indicate that oil shales consisting predominantly of Type I kerogen and little of Type II kerogen are of immature in character that is they do not reach in oil generation window yet. This is also supported by very low estimated PI values (average 0.02) (Table 1). CPI value of more than 1 and higher Pr and $\mathrm{Ph}$ concentrations with respect to n-alkanes imply that oil shales are not mature (Table 2). $22 \mathrm{~S} /(22 \mathrm{R}+22 \mathrm{~S})$ homohopane ratio increases with increasing maturity and attains equilibrium at the ratio of $0.57-0.62$ which can be used for the immatureearly maturity range (Peters and Moldowan 1993; Waples and Machihara 1991). 20S/(20R +20S) sterane isomerization and $\boldsymbol{\beta} \boldsymbol{\beta} /(\boldsymbol{\alpha} \boldsymbol{\alpha}+\boldsymbol{\beta} \boldsymbol{\beta})$ sterane isomerization attain equilibrium at the ratios of $0.52-0.55$ and $0.67-0.71$, respectively, and these ratios can be used for the immature-maturity range (Seifert and Moldowan 1986). In addition, Ts/(Ts + Tm) and diasterane/ sterane ratio also increases with increasing maturity. In a general sense, $22 \mathrm{~S} /(22 \mathrm{R}+22 \mathrm{~S})$ homohopane, $20 \mathrm{~S} /(20 \mathrm{R}+20 \mathrm{~S})$ sterane, $\mathrm{Ts} /(\mathrm{Ts}+\mathrm{Tm})$ and diasterane/sterane ratios reflect immature character of oil shales (Table 3). The average $\boldsymbol{\beta} \boldsymbol{\beta} /$ $(\boldsymbol{\alpha} \boldsymbol{\alpha}+\boldsymbol{\beta} \boldsymbol{\beta})$ sterane ratio of 0.27 indicates that oil shales are of early mature character and are at the oil generation window (Fig. 11). MA(I)/MA(I+II), TA(I)/TA(I+II) and TA $\left[\mathrm{C}_{20} /\right.$ $\left(\mathrm{C}_{20}+\mathrm{C}_{28}\right.$ 20R)] steroid ratios increase from 0 to $100 \%$ with increasing maturity, and they can be used for describing early mature-late mature range (Seifert and Moldowan 1978; Mackenzie et al. 1981; Peters et al. 2005; Beach et al. 1989). MA(I)/MA(I+II) (0.08-0.04), TA(I)/TA(I+ II) (0.11-0.05) and $\mathrm{TA}\left[\mathrm{C}_{20} /\left(\mathrm{C}_{20}+\mathrm{C}_{28} 20 \mathrm{R}\right)\right](0.80-0.25)$ steroid ratios of the studied oil shales reflect immature-mature range. 2-MP and 3MP isomers $(\boldsymbol{\beta} \boldsymbol{\beta} /(\boldsymbol{\alpha} \boldsymbol{\alpha}+\boldsymbol{\beta} \boldsymbol{\beta})$-isomers $)$ are thermally more stable than 1-MP and 9- MP ( $\alpha$-isomers) isomers, and $\beta / \alpha$ MP ratio (MPI-3) can be used for maturity estimation (Radke et al 1982). For the studied oil shales, this value has been calculated to be very high (1.49-1.34), indicating mature organic matter. During the maturation, increase in 4-MDBT with respect to 1-MDBT is attributed to higher thermal stability (Radke et al. 1986; Dzou et al. (1995) . In the studied oil shales, the 4-MDBT content is higher than 1-MDBT content, and the calculated MDR is in the range of 4.25 to 3.31, reflecting mature organic matter. Maturity results obtained from MP and MDBT data are not compatible with immature source rock assessment using the pyrolysis, GC and other biomarker data. Budzinski et al. (1995) have shown that methyl-phenanthrene distributions vary with respect to deposition conditions. In their study on oil and condensate set, Chakhmakhchev et al. (1997) stated that MDR is not dependent on vitrinite reflectance. It has been revealed that the depositional environment and lithology have an effect on the distribution of ADBTs in coal samples at maturity levels below vitrinite reflectance 

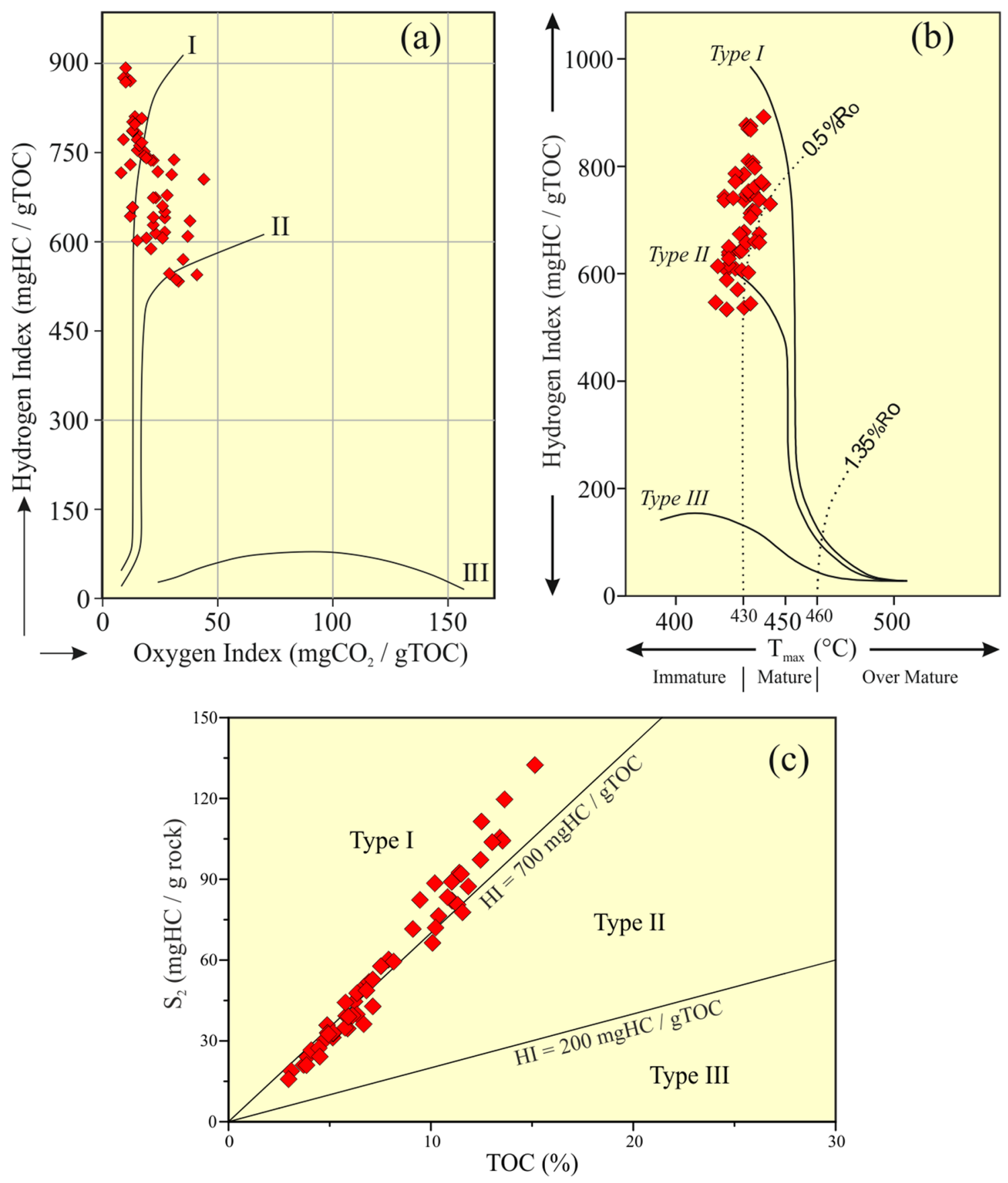

Fig. 9 Plots of (a) HI versus OI, (b) HI versus Tmax and (c) $\mathrm{S}_{2}$ versus TOC for the analyzed oil shale samples from the Alpagut section 

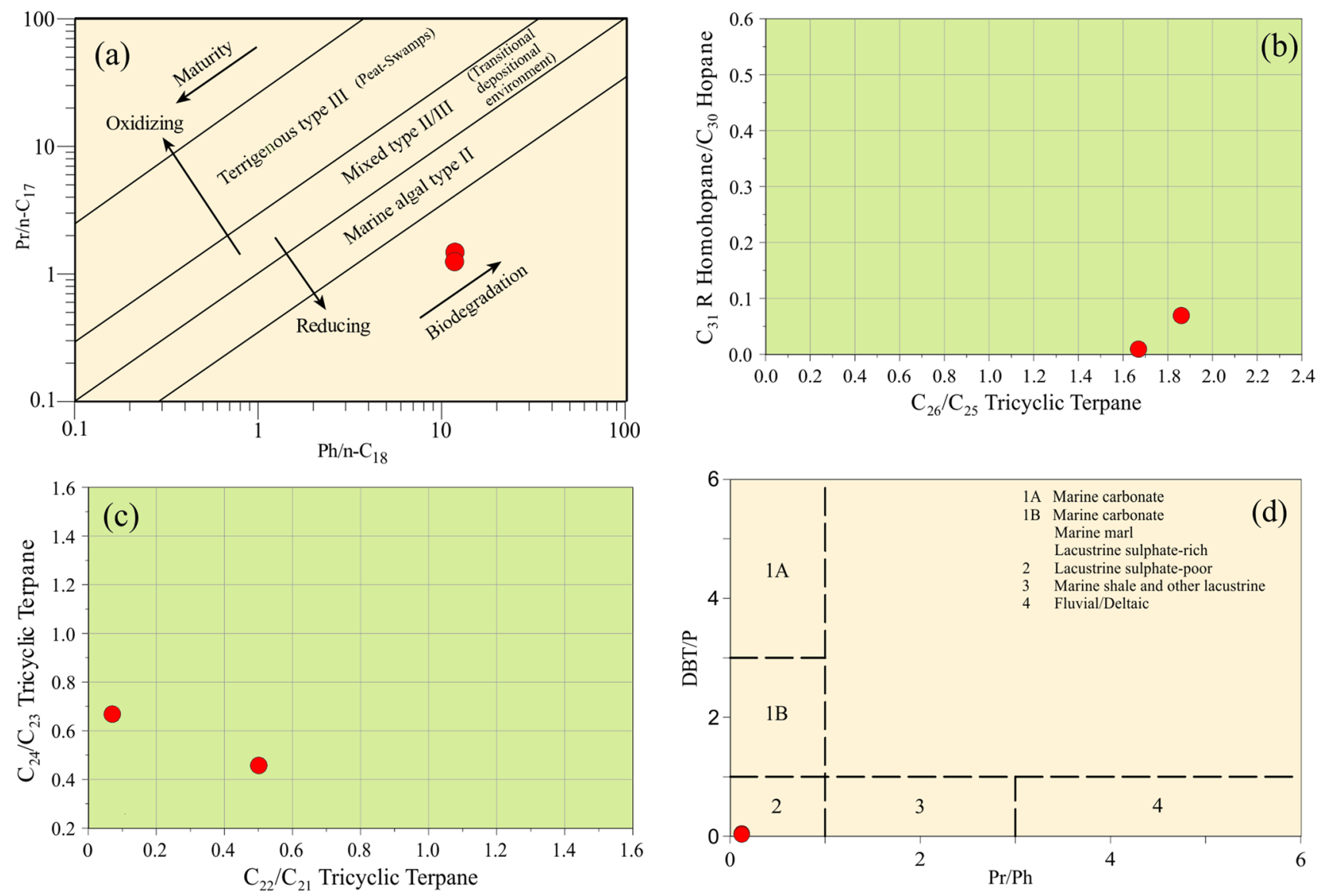

Fig. 10 Bivariate diagrams of $\mathrm{Pr} / \mathrm{n}-\mathrm{C}_{17}$ versus $\mathrm{Ph} / \mathrm{n}-\mathrm{C}_{18}$ (a), $\mathrm{C}_{31} \mathrm{R}$ homohopane/ $\mathrm{C}_{30}$ hopane versus $\mathrm{C}_{26} / \mathrm{C}_{25}$ tricyclic terpane $(\mathbf{b}), \mathrm{C}_{24} / \mathrm{C}_{23}$ versus $\mathrm{C}_{22} / \mathrm{C}_{21}$ tricyclic terpane (c) and DBT versus $\mathrm{Pr} / \mathrm{Ph}$ for the oil shale extract samples from the Alpagut section

values of 1.35 (Radke et al. 2000; Dzou et al. 1995). Therefore, very high MPI-3 and MDR ratios of the studied oil shales might be related to deposition environment, organic matter input and lithology rather than maturity.

\section{Conclusions}

The Miocene Alpagut oil shales in the Çankırı-Çorum basin with very high TOC contents have an excellent source rock character. Very high $\mathrm{S}_{2}$ and $\mathrm{HI}$ values and very low OI values and biomarker data show that studied shales are represented by organic matters of predominantly Type I kerogen and little Type II kerogen (dominantly algal and bacterial). Oil shales are characterized by high organic matter content, dominantly Type I kerogen and very high HI, Potential Yield (PY) values and very high hydrocarbon potential, and they are capable of generating hydrocarbon and thus have a high oil potential. High $\mathrm{C}_{26} / \mathrm{C}_{25}, \mathrm{C}_{24} / \mathrm{C}_{23}$ and low $\mathrm{C}_{22} / \mathrm{C}_{21}$ tricyclic terpane, $\mathrm{C}_{31} \mathrm{R} / \mathrm{C}_{30}$ hopane and $\mathrm{DBT} / \mathrm{P}$ ratios indicate that studied oil shales were deposited in a lacustrine environment. Moreover, very low $\mathrm{Pr} / \mathrm{Ph}$ ratios imply that deposition environment has an anoxic character.

Low $\mathrm{T}_{\max }$ and PI values obtained from pyrolysis analysis, high CPI and $\mathrm{Pr} / \mathrm{nC}_{17}$ and $\mathrm{P} / \mathrm{nC}_{18}$ ratios and very low $22 \mathrm{~S} /$ $(22 \mathrm{~S}+22 \mathrm{R})$ homohopane, $20 \mathrm{~S} /(20 \mathrm{~S}+20 \mathrm{R})$ sterane, diasterane/sterane and $(\mathrm{Ts} /(\mathrm{Ts}+\mathrm{Tm})$ ratios obtained from $\mathrm{GC}$ 

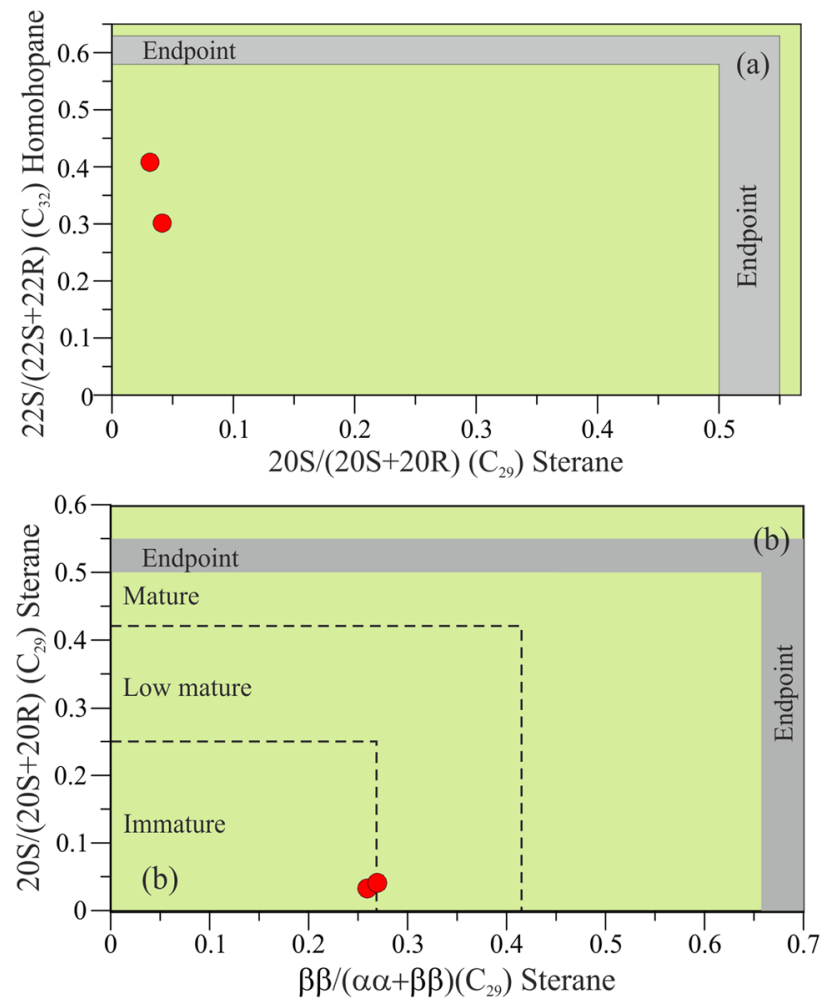

Fig. 11 Bivariate diagrams of $22 \mathrm{~S} /(22 \mathrm{~S}+22 \mathrm{R})$ homohopane versus $20 \mathrm{~S} /(20 \mathrm{~S}+20 \mathrm{R})$ sterane $(\mathbf{a})$, and $20 \mathrm{~S} /(20 \mathrm{~S}+20 \mathrm{R})$ sterane versus $\beta \beta /$ $(\alpha \alpha+\beta \beta)$ sterane $(\mathbf{b})$ for the oil shale extract samples from the Alpagut section

analysis point out that studied oil shales are not mature yet and not regarded as being reached the oil generation window.

Although organic matter they contain may greatly transform to hydrocarbon (particularly oil), studied oil shales are considered as potential source rocks that have not been experienced any hydrocarbon generation.

Acknowledgements The authors would like to thank the Geochemical Laboratory of the Turkish Petroleum Co. (TPAO) for their support in analyzing the data. We also thank Prof. Dr. Hükmü Orhan who revised and improved the language of the paper.

Funding The Karadeniz Technical University (KTU) Scientific Research Foundation (Projects No: 8740) financially supported this study.

\section{Declarations}

Conflict of interest The authors declare that they have no known competing financial interests or personal relationships that could have appeared to influence the work reported in this paper.

Ethical approval The article is an original article, and we declare that the article has not been published before and is not being submitted to any other journal for publication.
Open Access This article is licensed under a Creative Commons Attribution 4.0 International License, which permits use, sharing, adaptation, distribution and reproduction in any medium or format, as long as you give appropriate credit to the original author(s) and the source, provide a link to the Creative Commons licence, and indicate if changes were made. The images or other third party material in this article are included in the article's Creative Commons licence, unless indicated otherwise in a credit line to the material. If material is not included in the article's Creative Commons licence and your intended use is not permitted by statutory regulation or exceeds the permitted use, you will need to obtain permission directly from the copyright holder. To view a copy of this licence, visit http://creativecommons.org/licenses/by/4.0/.

\section{References}

Barrier E, Vrielynck, B, Brouillet JF, Brunet MF (Contributors : Angiolini L, Kaveh F, Plunder A, Poisson A, Pourteau A, Robertson A, Shekawat R, Sosson M, Zanchi A) (2018). Paleotectonic Reconstruction of the Central Tethyan Realm. Tectonono-Sedimentary-Palinspastic maps from Late Permian to Pliocene. CCGM/ CGMW, Paris, http://www.ccgm.org. Atlas of 20 maps (scale: $1 / 15000000)$.

Beach F, Peakman T, Abbott G, Sleeman R, Maxwell J (1989) Laboratory thermal alteration of triaromatic steroid hydrocarbons. Org Geochem 14:109-111. https://doi.org/10.1016/0146-6380(89) 90024-7

Bender F (1955) Lignite occurrences of the Çorum, Alpagut-Dodurga area, MTA Report no: 2949 (Turkish), Ankara.

Birgili Ş, Yoldaş R, Ünalan G (1975) Geology and petroleum possibilities of Çankırı-Çorum basin, MTA Report no: 5621 (Turkish), Ankara.

Blumenthal M (1938) Geological report of lignite between İskilipOsmancık and Tosya Türkiye, MTA Report no: 676 (Turkish), Ankara.

Budzinski H, Garrigues P, Connan J, Devillers J. Domine D, Radke M, Oudin JL (1995) Alkylated phenanthrene distributions as maturity and origin indicators in crude oils and rock exracts. Geochimica et Cosmochimica Acta 59:2043-2056. https://doi.org/10.1016/ 0016-7037(95)00125-5

Chakhmakhchev A, Suzuki M, Takayama K (1997) Distribution of alkylated dibenzothiophenes in petroleum as a tool for maturity assessments. Org Geochem 26(7-8):483-489. https://doi.org/ 10.1016/S0146-6380(97)00022-3

Dembicki H Jr (2009) Three common source rock evaluation errors made by geologists during prospect or play appraisals. AAPG Bull 93(3):341-356. https://doi.org/10.1306/10230808076

Dzou L, Noble R, Senftle J (1995) Maturation effects on absolute biomarker concentration in a suite of coals and associated vitrinite concentrates. Org Geochem 23(7):681-697. https://doi. org/10.1016/0146-6380(95)00035-D

Ekweozor C, Udo O (1988) The oleananes: origin, maturation and limits of occurrence in Southern Nigeria sedimentary basins. In Organic Geochemistry In Petroleum Exploration. Elsevier, pp 131-140 https://doi.org/10.1016/B978-0-08-037236-5.50019-1

Ekweozor C, Okogun J, Ekong D, Maxwell J (1979) Preliminary organic geochemical studies of samples from the Niger delta (Nigeria) I Analyses of crude oils for triterpanes. Chem Geol 27(1-2):11-28

Gelpi E, Schneider H, Mann J, Oro J (1970) Hydrocarbons of geochemical significance in microscopic algae. Phytochemistry 9(3):603-612. https://doi.org/10.1016/S0031-9422(00)85700-3

Grantham PJ, Posthuma J, Baak A (1983) Triterpanes in a number of far-eastern crude oil. In: Bjoroy $\mathrm{M}$ et al (eds) Advances in 
Organic Geochemistry 1981. J. Wiley and Sons, New York, pp $675-683$

Hughes WB, Holba AG, Dzou LI (1995) The ratios of dibenzothiophene to phenanthrene and pristane to phytane as indicators of depositional environment and lithology of petroleum source rocks. Geochim Cosmochim Acta 59(17):3581-3598. https://doi.org/10. 1016/0016-7037(95)00225-O

Kara H, Erten H, Karaosmanoğlu A, Gürsoy B, Güçlüer N, Polat N (1990) Geology of the Çorum, Osmancık, Dodurga, Alpagut lignite fields, MTA Report no: 8986 (Turkish), Ankara

Kara-Gülbay R, Kırmacı MZ, Korkmaz S (2012) Organic geochemistry and depositional environment of the Aptian bituminous limestone in the Kale Gümüşhane area (NE-Turkey): An example of lacustrine deposits on the platform carbonate sequence. Org Geochem 49:6-17. https://doi.org/10.1016/j.orggeochem.2012.05.006

Kaymakçı N (2000) Tectono-stratigraphical evolution of the Çankırı basin (Central Anatolia, Turkey). Thesis (Ph. D.) Utrectht University, The Netherlands

Ketin, İ. (1966). Tectonic Units of Anatolia (Asia Minor) . Bulletin of the Mineral Research and Exploration, 66 (66). https://dergipark. org.tr/tr/pub/bulletinofmre/issue/3892/51961

Khoitiyn T (2016) Organic geochemical characteristics and depositional environment of oil shale sequence in the Alpagut-Dodurga area, Çorum/Turkey. Thesis (M.Sc.) Karadeniz Technical University, Trabzon, Turkey

Kıpçak C (1947) Report on Çorum-Dodurga lignites, MTA report no: 1733 (Turkish), Ankara

Mackenzie A, Lewis C, Maxwell J (1981) Molecular parameters of maturation in the Toarcian shales, Paris Basin, France-IV Laboratory thermal alteration studies. Geochim Cosmochim Acta 45(12):2369-2376

Moldowan JM, Seifert WK, Gallegos EJ (1985) Relationship between petroleum composition and depositional environment of petroleum source rocks. AAPG Bull 69(8):1255-1268. https://doi.org/ 10.1306/AD462BC8-16F7-11D7-8645000102C1865D

Özçelik Y, Öztaş Y (2000) Geology and petroleum possibilities of Çankırı basin, TPAO report no: 4150, (Turkish), Ankara

Pekmezciler S (1957) Geology report of Çorum-Dodurga lignites, MTA report no: 2540 (Turkish), Ankara

Peters KE, Moldowan JM (1993) The biomarker guide: Interpreting molecular fossils in petroleum and ancient sediments. Englewood Cliffs, N.J., Prentice-Hall

Peters KE, Walters CC, Moldowan J (2005) The biomarker guide: Biomarkers and isotopes in petroleum exploration and earth history, vol. 2, 2nd ed. Cambridge University Press, Cambridge, pp. 475-1155

Philp RT, Gilbert T (1986) Biomarker distributions in Australian oils predominantly derived from terrigenous source material. Org Geochem 10(1-3):73-84. https://doi.org/10.1016/0146-6380(86) 90010-0

Radke M, Willsch H, Leythaeuser D, Teichmüller M (1982) Aromatic components of coal: relation of distribution pattern to rank. Geochim Cosmochim Acta 46(10):1831-1848. https://doi. org/10.1016/0016-7037(82)90122-3

Radke M, Welte D, Willsch H (1986) Maturity parameters based on aromatic hydrocarbons: Influence of the organic matter type. Org Geochem 10(1-3):51-63. https://doi.org/10.1016/01466380(86)90008-2

Radke M, Welte D, Willsch H (1991) Distribution of alkylated aromatic hydrocarbons and dibenzothiophenes in rocks of the Upper Rhine Graben. Chem Geol 93(3-4):325-341. https://doi. org/10.1016/0009-2541(91)90122-8

Radke M, Vriend S, Ramanampisoa L (2000) Alkyldibenzofurans in terrestrial rocks: influence of organic facies and maturation. Geochim Cosmochim Acta 64(2):275-286. https://doi.org/10.1016/ S0016-7037(99)00287-2
Riboulleau A, Schnyder J, Riquier L, Lefebvre V, Baudin F, Deconinck JF (2007) Environmental change during the Early Cretaceous in the Purbeck-type Durlston Bay section (Dorset, Southern England): a biomarker approach. Org Geochem 38(11):1804-1823. https://doi.org/10.1016/j.orggeochem.2007.07.006

Riva A, Caccialanza PG, Quagliaroli F (1988) Recognition of $18 \beta$ (H)oleanane in several crudes and Tertiary-Upper Cretaceous sediments Definition of a new maturity parameter. Org Geochem 13(4-6):671-675. https://doi.org/10.1016/0146-6380(88)90088-5

Seifert WK, Moldowan JM (1978) Applications of steranes, terpanes and monoaromatics to the maturation, migration and source of crude oils. Geochim Cosmochim Acta 42(1):77-95. https://doi. org/10.1016/0016-7037(78)90219-3

Seifert WK, Moldowan JM (1986) Use of biological markers in petroleum exploration. Methods Geochem Geophys 24:261-290

Şenalp, M., 1981. Sedimantological studies of the continental Formations around the region of Çankırı-Çorum Basin. Bull. of the Geological Society of Turkey 24, 65-74.

Şengör AC, Yılmaz Y (1981) Tethyan evolution of Turkey: a plate tectonic approach. Tectonophysics 75(3-4):181-241. https://doi. org/10.1016/0040-1951(81)90275-4

Şengüler İ, Kara Gülbay R, Korkmaz S (2014) Organic geochemical charactersitics of miocene oil shale depositsin the eskişehir basin, Western Anatolia, Turkey. Oil Shale 31:315-336. https://doi.org/ 10.3176/oil.2014.4.02

Taka M, Şengüler İ, Şener M (1992) Geology and utilization possibilities of the oil shale deposit of Dodurga (Çorum) area, MTA Report no: 9529 (Turkish), Ankara.

Tissot BP, Welte DH (1984) Petroleum formation and occurrence. Springer Verlag, Heidelberg

Toprak S (1996) Determination of depositional environments and properties of coals located in the vicinity of Alpagut-Dodurga (Osmancik-Çorum) region. Thesis (Ph.D.), Hacettepe University, Ankara, Turkey.

Turnovsky K (1964) Micropaleontological investigation report of the Dodurga lignites, MTA report no: 2996 (Turkish), Ankara.

Tüysüz O, Dellaloglu A (1994) Early Tertiary palaeogeographic evolution of Çankırı Basin and its surrounding in Central Anatolia. Proceedings of $10^{\text {th }}$ Turkish Petroleum Congress, Ankara,

Udo O, Ekweozor C (1990) Significance of oleanane occurrence in shales of Opuama Channel Complex. Niger Delta Energy and Fuels 4(3):248-254. https://doi.org/10.1021/ef00021a006

Uğuz MF, Sevin M, Duru M (2002) Geological map of Turkey, Sinop Districht, MTA, Ankara.

Varol B, Araz H, Karadenizli L, Kazancı N, Seyitoğlu G, Şen Ş (2002) Sedimentology of the Miocene evaporitic succession in the north of Çankiri-Çorum basin, central Anatolia, Turkey. Carbonates Evaporites 17:197-209. https://doi.org/10.1007/ BF03176485

Volkman JK, Alexander R, Kagi RI, Noble RA, Woodhouse CW (1983) A geochemical reconstruction of oil generation in the Barrow Sub-basin of Western Australia. Geochim Cosmochim Acta 47(12):2091-2105. https://doi.org/10.1016/0016-7037(83) 90034-0

Wang L, Wang C, Li Y, Zhu L, Wei Y (2011) Sedimentary and organic geochemical investigation of Tertiary lacustrine oil shale in the central Tibetan plateau: palaeolimnological and paleoclimatic significance. Int J Coal Geol 86(2-3):254-265. https://doi.org/ 10.1016/j.coal.2011.02.011

Waples DW, Machihara T (1991) Biomarkers for geologists-a practical guide to the application of steranes and triterpanes in petroleum geology (METHODS IN EXPLORATION SERIES). https://www. amazon.com/Biomarkers-Geologists-Application-TriterpanesExploration/dp/0891816593

Wedding H (1966) Report on the studies of coal occurrences in the Alpagut-Dodurga field, MTA report no: 3925 (Turkish), Ankara. 
Whitehead E (1973) Molecular evidence for the biogenesis of petroleum and natural gas. International Association of Geochemistry and Cosmochemistry, vol. 2. Clarke Company, Washington DC 1973:158-211

Whitehead E (1974) The structure of petroleum pentacyclanes. In: Tissot BP, Bienner F (eds) Advances in Organic Geochemistry. Editions Technip, Paris, pp 225-243

Yalcin Erik N, Aslan Y, Büyüksaraç A (2018) Organic geochemical chracteristics of Alpagut-Dodurga (Çorum) coals. Pamukkale Univ J Eng Sci 24(3):566-575. https://doi.org/10.5505/pajes. 2017.97513

Yavuz N, Culha G, Demirer ŞS, Utescher T, Aydın A (2017) Pollen, ostracod and stable isotope records of palaeoenvironment and climate: Upper Miocene and Pliocene of the Çankırı Basin
(Central Anatolia, Turkey). Palaeogeogr Palaeoclimatol Palaeoecol 467:149-165. https://doi.org/10.1016/j.palaeo.2016.04.023

Yavuz N, Demirer ŞS (2018) Palynology of the Kılçak formation (Early Miocene) from Central Anatolia: Implications for palaeoclimate and palaeoenvironment. Bull Mineral Res Explor 156:117-136

Zengin M (2006) Potential of Epithermal Ore And Blue Chalsedony In Northeast Part of Osmancik (Çorum) Thesis (M.Sc.) İstanbul Technical University, Istanbul, Turkey.

Publisher's Note Springer Nature remains neutral with regard to jurisdictional claims in published maps and institutional affiliations. 